Santa Clara University

Scholar Commons

History

College of Arts \& Sciences

$9-2013$

\title{
Breaking the Ties: French Romantic Socialism and the Critique of Liberal Slave Emancipation
}

Naomi J. Andrews

SantaClaraUniversity, nandrews@scu.edu

Follow this and additional works at: http://scholarcommons.scu.edu/history

Part of the European History Commons, and the Feminist, Gender, and Sexuality Studies Commons

\section{Recommended Citation}

Andrews, Naomi J. (2013). Breaking the Ties: French Romantic Socialism and the Critique of Liberal Slave Emancipation. The Journal of Modern History, Vol. 85, No. 3 (September 2013) , pp. 489-527. Published by: The University of Chicago Press. Article DOI: 10.1086/668500. Article Stable URL: http://www.jstor.org/stable/10.1086/668500

This Article is brought to you for free and open access by the College of Arts \& Sciences at Scholar Commons. It has been accepted for inclusion in History by an authorized administrator of Scholar Commons. For more information, please contact rscroggin@scu.edu. 


\title{
Breaking the Ties: French Romantic Socialism and the Critique of Liberal Slave Emancipation*
}

\author{
Naomi J. Andrews
}

Santa Clara University

What we especially call slavery is only the culminating and pivotal point where all of the suffering of society comes together.

(Charles Dain, 1836)

The principle of abolition is incontestable, but its application is difficult.

(Louis Blanc, 1840)

In 1846, the romantic socialist Désiré Laverdant observed that although Great Britain had rightly broken the ties binding masters and slaves, "in delivering the slave from the yoke, it has thrown him, poor brute, into isolation and abandonment. Liberal Europe thinks it has finished its work because it has divided everyone." 1 Freeing the slaves, he thus suggested, was only the beginning of emancipation. Laverdant's comment reflects a broader political conversation about the individual and society that was ongoing in France during the 1830s and 1840s in which the issues of colonial slavery, metropolitan wage labor, and imperial expansion in Algeria were intertwined. 2The July Monarchy, the temporal frame for this discussion, marked a period in which French society suffered the driving forces of modernization alongside the necessity to reconstruct the social order in the wake of revolution. In this dynamic context, Laverdant and his fellow romantic socialists articulated the relationship between freedom and servitude in very different terms than did their liberal contemporaries, whether in regard to the slave-owning colonies or metropolitan France. As socialists contemplated emancipation, they feared that freed slaves would be abandoned socially and made subject to a European wage labor system, problems they identified with liberal individualism and capitalism. They offered an alternative approach to slave emancipation based on the socialist construct of "association." Association challenged the priorities of liberal individualism and laissez-faire economics and emphasized the socialist values of interdependence and social stability in their place. 
Both within and beyond slavery debates, French socialists were skeptical of Enlightenment narratives of progress and the primacy of the individual.3 In their associationist proposals for slave emancipation, they offered an account of modernity different from the liberal one of individual rights and freedoms that dominated discussions of slavery. This "alternative modernity" rested on an apprehension of progress that did not take as given the liberal ideals of individual autonomy and selfpossession and sought to remedy problems experienced in the modern world in nonliberal ways. 4 Their divergent definition of freedom illustrates the fact that the conquest of autonomous individuality was an uneven, unpredictable, and contested process. This article explores the proposals for slave emancipation that socialists developed during the July Monarchy amid contemporary discussions equating workers in metropolitan France and slaves in the French colonies. As I demonstrate below, the either/or posited by liberal definitions of freedom and servitude elides a gray zone of mutual dependency within which romantic socialism was articulated. $\underline{5}$ $* * *$. Jump To Section...

The first French Republic legally ended slavery in 1794 in acknowledgment of the successful slave revolt on Saint Domingue and humanitarian concerns in the metropole. Reimposed by Napoleon, slavery remained legal in France's Caribbean and Indian Ocean colonies through the July Monarchy and was permanently abolished only under the Second Republic in the spring of 1848.6For educated Frenchmen across the political spectrum, colonial slavery was both a humanitarian and a political problem. While metropolitan politicians acknowledged the necessity of ending slavery both on economic and on moral grounds, they were stymied by the politics of implementing emancipation. Meanwhile, the abolition of slavery in British plantation colonies between 1834 and 1838 put the issue high on the political agenda in France during the July Monarchy.

British leadership in the antislavery debate dated from the eighteenth century, and during the same period British liberal theories of political economy dominated 
discussions of emergent capitalism in France and elsewhere. The rhetoric of liberalism, in fact, simultaneously structured thinking about economic policy and the framework through which the end of slavery was debated and anticipated throughout the slave-owning West. Alexis de Tocqueville exemplified this individualist mind-set when he noted of the British example that "in an instant almost a million men together went from extreme servitude to total freedom, or better put, from death to life."ㅌarly socialists, however, centrally concerned with the state of the European working classes, were deeply skeptical of free labor and market forces as solutions to any version of servitude. They considered liberalism the cause of much contemporary suffering rather than a source of "life" and thus questioned the liberal narrative of "total" freedom. For socialists, then, the obstacle was not freeing slaves but, rather, rebuilding postemancipation society without replicating the problems of the metropole. Reflecting the discrepancy between liberal and socialist perspectives on emancipation, the socialist Charles Dain exhorted the liberal abolitionist Victor Schœlcher to "please produce his program for liberty." $\underline{8}$ Socialists" opposition to the liberal discourse of free trade and free labor thus dictated their approach to the issue of labor overall, whether wage labor in Europe or forced labor in the colonies.

The problems socialists saw with liberal slave emancipation are also, interestingly, central to current scholarship on the subject. In the last generation, historians of slavery and emancipation have foregrounded the social realities of life after abolition, scrutinizing the multivalent dimensions of "freedom" and the persistent continuities with slavery found in postemancipation societies. 9 One naive assumption that has been fully dispensed with by this scholarship is the notion that freedom was an end in itself. Historians no longer suggest that the legal transition from enslaved to free was the definitive moment in emancipation, emphasizing instead the long-term structural change that was its necessary correlate. 10 At the same time, scholars have demonstrated that in an age of democratization and individual rights, distaste for the moral compromise inherent in slave ownership was a primary motivation for advocates of abolition. Antislavery campaigners, both elite and popular, wanted slavery "stamped out" in the interests of all involved, not least the slave owners. 11 
This discourse of "moral narcissism" privileged the coup de grâce of emancipation and minimized the dislocation, systemic inequalities, and economic distress that would inevitably characterize life for the formerly enslaved.12 Liberal ideals of individual autonomy notwithstanding, the act of emancipation was far from liberatory and was in many ways as economically painful to newly freed people as it was to plantation owners, if not more so, as it kept the former slaves still largely dependent on their former masters and with limited access to economic resources. $\underline{13}$

Similar dynamics of dislocation and social insecurity that would later emerge in postemancipation societies also affected postrevolutionary France, the environment that produced early socialism. 14 Decades of revolution and warfare, alongside the rapid changes brought by industrialization, forced French society to rebuild on new terms. In this context, romantic socialists emerged both as critics of the ascendant liberal paradigm and as bold theorists of a different approach to the social order. The French empire's recent history and ongoing experience of interracial and interclass violence also informed socialism's development. 15 Indeed, socialism in these years was in no small part designed to stave off further disorder, as repeated invocations to “organize" labor demonstrate.

Socialists were particularly troubled by what they saw as the dangers of atomization, and they described their concerns in discussions of colonial slaves and of metropolitan workers simultaneously. They feared that former slaves in the French empire would become increasingly proletarianized, just as wage laborers had become in the metropole. The unfolding of British emancipation, particularly the impoverishment and legal marginalization of former slaves, appeared to validate these fears. In response, a number of French socialists, including several of Creole planter origin, developed proposals for ending slavery based on the idea of association. 16 Association was a key concept for the French Left in these years, especially among organized laborers and within socialist circles. Shorthand for a diverse array of cooperative economic and social structures, association connoted an alternative social order based on interdependence and cross-class collaboration that would mitigate the 
vulnerability and rootlessness endemic to the wage labor system. Like metropolitan versions, associationist programs for slave emancipation rested on a worldview that diverged from liberalism by prioritizing social cohesion and security over absolute individual liberty. Socialists believed that association would protect the newly freed black population in the colonies from the fate of workers in Europe. In transferring the concept of association from the metropole to the colonies, however, their programs effectively tolerated the racial hierarchy inherent in the master-slave relationship.

Historians of abolition have understandably cast a jaundiced eye on these plans for slave emancipation. 17 Read in the context of the early nineteenth century, in which the dominant vocabulary of emancipation drew on liberal paradigms of individual autonomy, socialist interventions on the slavery issue are confusing, to say the least. In contrast to the overwhelming majority of antislavery literature from the era, they elude neat categorization as for or against genuine independence for enslaved people. 18 On the one hand, they echo the foot-dragging that pervaded slavery debates in July Monarchy France among both colonial and antislavery interests. On the other hand, they mirror liberal assertions of the humanity of the enslaved, including calls for their emancipation. From a twenty-first-century perspective, the socialist version of emancipation clearly falls short of modern definitions, as its goal was not the creation of legal subjects, independent of either directly coercive or paternalist authority. Instead, socialists privileged the consolidation of ties that they conceived of as familial bonds. Furthermore, socialist emancipation programs fit comfortably with the paternalist rhetoric used by proslavery advocates in France and elsewhere in the midnineteenth century. 19 Historians of abolition have thus quite reasonably questioned both the socialists' commitment to abolition and the genuineness of the emancipation they envisioned.

Just as important, the socialists' critique of liberalism also underpinned their endorsements of French imperial investments, both in the "old" slave-owning colonies and in the recently conquered territory of Algeria. Indeed, their consistent support for the empire is best understood as part of a complex interaction with their metropolitan 
concerns about the pitfalls of liberalism. 20 The socialist Louis Blanc, for example, counseled his contemporaries against exporting "hideous ruins" to France's old and new colonies for fear of reproducing those "social institutions that make our old Europe a horrible field of battle." 21 An important illustration of this colonialmetropolitan interaction can be seen in the way socialists used the powerful and multivalent language of slavery. Socialists of all stripes deployed this rhetoric to evoke the suffering and moral depredations of the forced-labor regime in the colonies, the perils and exploitation of industrial wage labor in urban Europe, and the status of women in marriage.22 In juxtaposing the parallel conversations about chattel slavery and wage slavery that ran throughout early socialists' writings, I hope to shed new

light on the way they understood the meaning and limits of freedom. Furthermore, my examination reveals racial fault lines in their conception of the human community, a community that socialists otherwise described in holistic terms. Racial thinking pervaded these discussions, ultimately leading these socialists to endorse, in the name of association, models of slave emancipation that failed to fundamentally challenge the old racial hierarchy. This article, by situating romantic socialism in the context of French imperial issues, aims not only to illuminate the colonial question in the early nineteenth century but also to deepen our understanding of early socialism itself.

\section{The Politics of Antislavery in July Monarchy France}

\section{Jump To Section...}

The antislavery debates of the Restoration and July Monarchy reflect two parallel narratives of slave liberation: the historical example of the first emancipation in the French empire in the 1790 s, particularly in relation to the Haitian Revolution, and the contemporary example of abolition in the British Empire and its impact on AngloFrench relations. These two emancipatory moments were dramatically different in both impetus and outcome, but both informed the approaches that French antislavery advocates, liberal and socialist, took to ending slavery. Most important, the key dilemmas with which socialist emancipation schemes were concerned-social stability and labor supply — were fundamental in both situations. 
The first slave emancipation of the modern world, enacted in the French empire in the 1790s, has been characterized by Laurent Dubois as a manifestation of "republican racism"- - his designation for restraints, cloaked in the universalist rhetoric of liberty and equality, that were imposed on newly freed colonial subjects.23 A stopgap measure in response to the reality of self-emancipation that the revolutionary commissioners found upon their arrival in Cap Français in 1792, the legal emancipations of 1793 (in parts of Haiti) and 1794 (by French legislative decree) in fact fell far short of full abolition on the liberal individualist model. The slave emancipation decreed by the revolutionary commissioners Félicité-Leger Sonthonax and Etienne Polverel entailed restraints on freedom of labor and mobility and put economic survival and labor supply above the absolute exercise of legal freedoms for former slaves. 24 The challenge of economic viability for the colony was paramount after emancipation, a reality attested to by Toussaint-Louverture's draconian decree of 1800 and constitution of 1801, in which military force was deployed to ensure that former slaves remained on the plantations. 25

Antislavery reformers of the 1830 s and 1840 s around the Atlantic were clearly influenced by the experiences of the first abolition, as the implicit threat of colonial violence looms large in their discussions. Themes of slave revolt are frequent in literary and theatrical artifacts of the period as well.26 Restoration-era antislavery advocates referred back to Toussaint's decrees in the context of the code ruraleimplemented by the Haitian president Jean-Pierre Boyer in 1826. These elites saw the utility of such measures, despite their opposition to slavery and sympathy for the Haitian Revolution.27 Although the same pragmatic considerations about labor supply that informed the first abolition remained central to nineteenth-century debates, the socialist proposals discussed below do not reference the eighteenth-century experience or Boyer's measures for their insights. Rather, socialists were responding explicitly to the liberal bent of both British and French antislavery in the nineteenth century and to what they perceived as liberal economic hegemony in the metropole.

Seymour Drescher has characterized British action during these years as "both a 
stimulus and a foil" to the other slaveholding nations of the Atlantic world, and none more so than France. 28 The British Empire moved to abolish, first, the transatlantic slave trade (in 1807) and, then, slavery in its Caribbean colonies (in a transitional process lasting from 1834 to 1838). Deeply influenced by both dissenting Protestant sects and emerging capitalist sentiment, British abolitionists successfully argued for and implemented emancipation in the vernacular of free labor and free trade. 29 After many decades of widespread popular petition campaigns, and following on resolutions (many unrealized) taken in 1823 to reform the condition of slaves, the British Parliament, enlarged by a recent influx of free-trade advocates, voted definitively in 1833 for slavery abolition. The emancipation implemented in 1834 began a seven-year "apprenticeship" for the newly freed, during which time they were expected to receive both religious and educational instruction in preparation for their assumption of full independence. During the apprenticeship period, former slaves were obligated to work unpaid for their former masters a prescribed number of hours per week, averaging four to five days, and strict vagrancy laws were enforced. British apprenticeship was saved from total hypocrisy only by the short horizon that it set for absolute emancipation, but even then contemporaries recognized the continuities with slavery inherent in the system. In the event, apprenticeship was abolished early, in 1838 , as a result of economic arguments for free labor's efficiency. $\underline{30}$

French abolitionists, government commissioners, and colonial planters keenly watched the developments in the British colonies, assessing the economic consequences, the threat of violence, and the racial and class implications of emancipation. 31 Initial relief at the peaceful nature of the process began to break down as the end of apprenticeship neared, giving way to new worries about the stability of the labor force-worries validated by eyewitness accounts of widespread abandonment of plantations upon real emancipation. 32 For both pro- and antislavery activists in France, the British antislavery movement proved critical: for the former, abolition was a nationalist plot devised to undermine French colonial power; for the latter, it was a model for propaganda and elite organizing, as well as a source of 
monetary and moral support. $\underline{33}$

Dormant under the Napoleonic Empire, the "second" French abolitionist movement proper began under the auspices of the Protestant-influenced Société de la Morale Chrétienne, and it took on institutional embodiment in response to British slave emancipation with the founding of the Société Française pour l'Abolition de l'Esclavage in 1834. 34 Whereas the British public played a significant role in the antislavery campaigns of the eighteenth and early nineteenth centuries, the French movement drew little from the lower and working classes until the very eve of emancipation. $\underline{35}$ Popular antislavery organizations never emerged in France, at least in part because of tensions produced by British leadership and by Britain's active- and intrusive - enforcement of international accords after 1815. These tensions were embodied in the "right to search" controversy of the 1840s, in which the British navy claimed the right to board French ships to ensure their compliance with slave trade abolition. $\underline{36}$ Thus, in addition to the example of the British abolition process, FrancoBritish diplomatic relations informed debates both on the slave trade and on slavery itself within France. 37

Although much of the French elite agreed on the necessity of abolition, opinion ranged from gradualism to immediatism, and those positions in turn encompassed varying opinions on the specific economic and moral issues at hand. Those within the ranks of the sociétésand the multiple government committees devoted to the question advocated gradual emancipation, including free-womb laws (which provided free status to all born after a certain date) and self-purchase provisions, and endorsed some form of compensation for dispossessed slave owners. Invariably, the French governments of the July Monarchy were reluctant to undertake the costly indemnity necessary to protect planter interests, which partly accounts for their hesitation. For example, leading liberals such as François Guizot and Adolphe Thiers, who were both antislavery in principle before they came to power, succumbed to political practicalities and pursued more gradualist approaches thereafter. $\underline{38}$

During the 1830s and 1840s, a series of commissions_led by important liberal 
figures such as Charles de Rémusat in 1838, Alexis de Tocqueville in 1839, and Albert de Broglie in 1840 - undertook systematic investigations of the conditions of slavery and the economic implications of emancipation. 39 Their reports generally favored eventual but not immediate emancipation, citing the religious and educational inferiority of the slave population and the need to elevate them morally before contemplating full emancipation. Although their proposals eschewed the British apprenticeship, some provisions nevertheless bore significant similarities to that system. Property rights were paramount: full indemnity for the plantation owners figured consistently in these plans, as did guarantees of a cheap and available labor force. None of these suggestions reached fruition, however, all of them falling victim to what a leading abolitionist, François Isambert, asserted was King Louis Philippe's determination to "adjourn indefinitely" the question of emancipation. $\underline{40}$

Throughout the July Monarchy, antislavery organizations and government commissions were thus relatively ineffectual, prompting calls for immediate and unconditional emancipation, mostly from within republican ranks, by the 1840 s. Among republican abolitionists, Victor Schœlcher, a Freemason who was at times associated with the socialists, was by far the most vocal and influential exponent of immediate emancipation, arguing for greater industrial development in the colonies and for small-scale credit banks for the former slaves. The first French abolitionist to visit independent Haiti, he advocated full political assimilation of the colonies to the metropole as part of his emancipation platform and pushed abolition through the French assembly in the early months of the Second Republic in 1848.41 Through his influential pamphlets and frequent contributions to French republican journals - most notably Le National and La Réforme-Schœlcher had an outsize influence on the politics and subsequent narrative of the French antislavery movement. His frequent battles with other abolitionists have strongly colored the historical legacy of several of these figures, including Jules Lechevalier and Charles Dain, discussed below. 42 By the 1840s, Schœlcher and other republicans such as Alphonse de Lamartine were openly criticizing the hesitation of the Guizot government. Nevertheless, although they argued for immediate and unencumbered emancipation, even Schœlcher 
equivocated on implementation questions such as compensation for slave owners. $\underline{43}$ The antislavery spectrum in France was thus never as radical or as socially broad based as that found in Great Britain at the time, and even some members of the republican opposition tended toward pragmatism until the spring of $1848 . \underline{4}$

During these years, the boundary between "socialist" and "republican" was porous. Many early socialists supported republican political organizations in addition to advocating more thoroughgoing social reforms. Conversely, republicans, especially those around La Réforme, favored the idea of association, although they broke with socialists over the issue of free trade. $\underline{45}$ Reflecting these continuities, socialists were in the mainstream of French antislavery sentiment to the extent that they opined publicly on the issue. Very few were official members of the organized antislavery movement, however, due to its elite character and the socialists' modest means. 46 Socialist-run journals ran antislavery articles while maintaining overall support for the colonies. Like their liberal and republican contemporaries, socialists employed the lexicon of freedom and servitude that dominated the economic and political rhetoric of the era, yet with a different valence. In all these discussions, their antipathy for Great Britain was formative. As in the specific case of antislavery, socialists generally used antiBritish language to denounce their antagonists under the July Monarchy—indeed, to articulate socialism itself.

Among socialist complaints was the rising influence in France of that British import, political economy.47 Socialists saw the materialism of political economy as the source of clinical callousness toward the working classes and as the ideological weapon of the bourgeoisie. In addition to generally objecting to finance capital, socialists opposed the Orleanist government, which they also associated with Great Britain. Indeed, significant affinities existed, both political and personal, between the Orleanist leadership and British liberals, embodied by their "patron saint," the French political theorist J.-B. Say. $\underline{48}$ Socialists thus consistently identified laissez-faire ideas with the social and political changes they experienced in the 1830s. Finance capital and free-trade legislation encouraged worker exploitation, especially in the form of 
lowered trade barriers, and British-aligned elites were accused of having "stolen" the worker-enabled Revolution of $1830 . \underline{49}$ Great Britain, however morally upstanding in its antislavery crusade, was thus inextricably bound in socialists' views with all that encouraged the pernicious doctrine of liberalism.

Anglophobia in early socialism and in socialists' antislavery views is not hard to identify. These sentiments in turn informed their approaches to slave emancipation. Charles Fourier denounced British apprenticeship and the compensation for slave owners embedded in the parliamentary emancipation bill of 1833: "And the fruit of this gigantic donation? Nothing other than a vicious circle, as we see in England, where ... one finds ... legions of poor, both theoretical and real." $\underline{50}$ Louis Blanc similarly indicted the British apprenticeship system as "the thing without the word," asserting that "this bill for emancipation rests on the proletariat." a number of key problems in their world to Great Britain. Their hostility to many things British contributed to their discomfort with liberal antislavery and shaped their own proposals. In their analogies between metropolitan wage "slaves" and colonial slaves, socialists developed these objections to liberalism and to the consequences of the unfettered freedom it preached. It is to this rhetorical parallel between workers and slaves that I now turn.

\section{Analogues in Servitude: Workers and Slaves in Socialist Rhetoric} Jump To Section...

When Montesquieu famously noted that "the condition of a slave is hardly more burdensome than that of a subject," he was using a powerful analogy, evoking for his educated readers the full extent of the unfreedom of political subjects. Likewise, in Rousseau's Social Contract, it is the enslavement of Europeans to their government that takes center stage. $\underline{52}$ Indeed, eighteenth-century European and British colonial political thought is replete with analogies between the status of the subject and that of the chattel slave, although with virtually no recognition of African enslavement in the Americas. $\underline{53}$ As a result both of the democratic revolutions of the eighteenth century and of the rise of industrialism, a worker/slave analogy also emerged during this era. 
Spurred in no small part by the contemporaneous articulation of the "social" as an object of scientific investigation, the analogy no longer referred solely to Europeans' political subjugation; it also invoked the working classes of Europe and the United States in their economic, social, and political subjection. 54 The rhetoric of slavery resonated in urbanizing Europe because it emphasized the powerlessness of the individual buffeted by rapid social transformations.

In the first half of the nineteenth century, the comparison between the slave and the worker was used at both ends of the political spectrum. Much to the chagrin of liberal abolitionists, both proslavery advocates and industrial reformers tended to favor the unfree but secure status of the chattel slave over that of the free but insecure industrial worker. 55 As Catherine Gallagher has shown, the analogy was central to the arguments of industrial reformers in England against the middle-class advocates of both free trade and slavery abolition in the 1820s. Rejecting what Charles Dickens later called "telescopic philanthropy," the writers she examines called upon the middle classes to consider the slaves on their doorstep rather than those far away in the colonies. $\underline{56}$ The potency of this comparison depended upon a presumed consensus on the intolerability of slavery. While the worker/slave analogy was arguably more accurate than the Enlightenment-era political version, it discounted the brutality of the slavery regime, sidestepping its necessary violence and the racial hierarchy that underwrote it. $\underline{57}$

Nevertheless, the analogy was not entirely off the mark. As one historian observes of postemancipation deprivations, "Many of these phenomena also occurred in Europe and North America, when the securities of the ancien régime were exchanged for the uncertainties of an industrialized society. However, that transition turned out to have been the start of unrivalled economic growth, which pushed such transitional drawbacks into oblivion." $\underline{58}$ Needless to say, the ultimate "oblivion" of these drawbacks was not known during the 1830s and 1840s, when they were all too evident, particularly to socialists. While there are many examples of the use of the analogy between the worker and the slave in socialist writings of this era, three of the 
most important advocates for the workers, Félicité Lamennais, Flora Tristan, and Louis Blanc, used it with particular effectiveness to make their arguments for reform of the wage labor system.

These three figures, each iconic in his or her own way, represent the range of early socialism in religious and political terms. Lamennais was a dissident Catholic priest and workers' champion who significantly influenced early socialism and working-class organizing, particularly through his paper L'Avenir and his popular critiques of the Catholic Church in France. $\underline{59}$ Lamennais's politics were radicalized over the course of the late Restoration and early July Monarchy, and in his scandalous work Paroles d'un croyant (1834) he announced his break with Rome. Lamennais's marriage of religiosity and socialist democracy was a hallmark of socialism during the 1830s and 1840s and through to the Second Republic.60 Tristan was a fervent advocate both of the working classes and of women, bringing together in her public persona and her political writings critiques that linked the oppression of the two groups. Connected early on to the Saint-Simonian and Fourierist schools of socialism, Tristan ultimately developed her own approach, advocating mutual aid and association to facilitate self-sufficiency among workers and challenging the hierarchical nature of the Fourierist and Saint-Simonian approaches. Her most important work of socialist philosophy was L'union ouvrière (1843), in which she developed her theory of class solidarity, emphasizing worker independence and democracy. Tristan also penned a number of travelogues in which she described the condition of women and of workers in other cultures, particularly Peru and Great Britain.61 Blanc was a "Jacobin socialist" during the 1840s and one of the few socialists in the provisional government after February 1848, chairing the Luxembourg commission on working conditions. 62 He emphasized the power of the state to orchestrate industrial relations, and his work Organisation du travail (1839) was highly influential in the development of working-class socialism. Seeing competition as the source of societal ills, Blanc proposed the development of social workshops for the coordinated efforts of various trades. A major critic of the Orleanist regime, his Histoire de dix ans, 1830-1840 (1841) provided documentary evidence of 
the corruption of the government and was a best seller during the $1840 \mathrm{~s}$.

In his work De l'esclavage moderne (1839), Lamennais framed the social question in these terms: "The proletarian is one who lives by his labor, and who could not live unless he did labor. ... The necessity of living makes the laborer dependent upon the capitalist, irremediably his subject: because in the purse of the one is the other's life." $\underline{63}$ By Lamennais's account, the worker and the slave existed in a similar state of dependence, in that the master held all the power-including the power to wait-with hunger constituting the "chains and rods" of the industrial labor force. Both populations, workers and slaves, depended on their masters and were valued only for the labor they provided. The main difference between them was in fact that the slave was a possession with value, while "if he [the worker] suffers, who cares? Another will replace him: as long as the ranks are full, hunger will quickly fill his place!"64 Flora Tristan made a similarly biting point in her Promenades dans Londres (1840), arguing that it was the division of labor that had reduced the working classes to cogs in the machine and stripped them of their independence and liberty: "The life of man is priced in silver; and when the needed task requires them to die, the industrialist gets off by raising salaries!!! But this is even worse than the slave trade! Behind this enormous monstrosity I see only cannibalism!!!" $\underline{65}$

In advocating for the workers, Lamennais and Tristan both asserted that the chattel slave was materially better off than his wage slave contemporaries in Europe. For Lamennais, the wageworker suffered more because he represented no unique value to the "master" but was, rather, a replaceable unit, whereas the capital investment sunk in the colonial slave required ongoing maintenance by the master. 66 Reflecting both the context of her observations (London) and the tenor of AngloFrench relations during this period, Tristan likewise argued that the slave was better off than the wageworker, averring that "the English proletariat ... [has] an existence so atrocious, that the blacks who have left the sugar plantations of Guadeloupe and of Martinique to go enjoy English freedom on Dominique and St. Lucia, return, when they can, to their masters." 67 By her account, England's factories were sites in which 
"reason [and] reflection are useless" and where there was no singing, no laughter, and none of the community that existed in French artisanal workshops. Tristan was unequivocal: "Since I have known the English proletariat, slavery is no longer, to my eyes, the greatest human misfortune. ... This position [that of the English proletarian] is so horrible, that to survive it, one must assume that the worker has superhuman courage or complete apathy." $\underline{68}$

Democracy was Lamennais's solution to worker enslavement. Tristan, on the other hand, proposed collective action through a grand association of workers, which she described in L'union ouvrière. This association would be realized by a nonviolent revolution, an implicit rejection of the recent episodes of worker-state violence in Lyon and Paris. Tristan suggested strengthening bonds of interdependence and developing a mutual-aid safety net in order to alleviate the extremes of independence and dislocation that industrial society meted out to workers. For both Lamennais and Tristan, the absence of any sort of social security was the ne plus ultra of capitalist wage labor. They saw the mutual dependence that defined colonial slavery as preferable precisely because reciprocal obligations between master and slave were therein institutionalized. Both writers discounted the influence of racial dynamics in the colonial arena, as exemplified by the fact that throughout De l'esclavage moderne Lamennais used the model of ancient Roman slavery to make his analogy, nowhere acknowledging the other "modern slavery" then under active debate in France. $\underline{69}$

Louis Blanc also drew a parallel between worker and slave in his critique of contemporary society, both colonial and metropolitan. Unlike Lamennais and Tristan, however, Blanc delved more deeply into the lived experience of colonial slaves and linked the two contexts explicitly, asserting that they were "intimately connected" and that "the solution to the problem ... must be double; it must consist in extirpating in a single blow, in the colonies, slavery and the seeds of the proletariat." 70 Reviewing Lamennais's 1839 book, De l'esclavage moderne, in La Revue du Progrès in 1840, Blanc observed that "the condition of white-skinned slaves is still preferable to that of black-skinned slaves," primarily because of the blacks' deprivation of family life. 71 
Nevertheless, this seemingly humanitarian position was compromised when Blanc defined the "slave" as "the day worker without work, the worker without a future," further noting that the living conditions of the colonial slave could be "envied" by the worker. 72 Blanc's review expressed genuine sympathy for colonial slaves, but in a way that exposed the limitations of the worker/slave analogy.

Racial presumptions clearly informed Blanc's views, as the tolerability of colonial slavery rested not only on the slaves' superior material circumstances but also, perversely, on their dehumanized psychology: "If slavery blunts the sensitivity of negroes and obscures their intelligence, they do not at least experience the horrible anguish of a free and proud soul at grips with the humiliations of poverty; they do not feel themselves, as the poor do, bleed inside from these wounds of the heart, the most painful of all!" 73 Deprived of the joys of family life, they at least did not suffer the pain of its loss, "the gnawing cares" or "remorse" of the workers unable to care for their children. Blanc's article is thus internally contradictory: full of protestations as to the "odious and degrading" state of the enslaved blacks of the colonies and assertions that the love of liberty was neither absent nor vanquished from their character yet contending that the superior sensitivity and intelligence of the "white slaves" of Europe, regardless of its derivation, caused them to suffer more. This latter insight led Blanc to accuse of madness the men who were busy working to abolish colonial slavery yet "refuse obstinately" to see the other, more painful form, beneath their noses: “METROPOLITAN SLAVERY, THE PROLETARIAT!”포

Blanc argued that in order for the problem of slavery, regardless of context, to be resolved, work would have to be made "attractive." Toward that end, he offered a thinly sketched associative model that would also ensure social stability. The solution to both forms of slavery would come from the French workers themselves, whose innovation - that is, association - promised the slaves' salvation. Left to their own devices, Blanc asserted, slaves would emancipate themselves through violent revolts. If French society were to follow the inspiration of the "people," however, the plight of both the worker and the slave would be ameliorated. 75 Blanc thus shared the ultimate 
goal that Lamennais and Tristan announced: the political and economic enfranchisement of the working classes of France through democracy and association. Leveraging the moral intolerability of chattel slavery in making the case for the emancipation of the proletariat, all three authors took the latter as their primary objective rather than the extirpation of the former, while using the bad odor associated with colonial slavery to make their case.

For these three authors, and for many others who employed the worker/slave analogy, the central conceit rested on both the parallels and the differences between the two groups. Like the slaves, workers lacked real autonomy, whether bodily or spiritual; they depended upon their masters for sufficient food and care to survive; they were, functionally, bought and sold as tools of the property-owning classes; and they lacked the freedom to defend their rights. On the other hand, the incentives that slave masters had to ensure the health and well-being of the slaves were absent in the wage labor system - which, in socialists' accounts, made the worker the more abject figure. Responding to claims that workers' freedom and material lives were superior to those of slaves, Lamennais responded that such differences were "fictive": "The body is not a slave, but the will is." 76 For early socialists, the logical conclusion to be drawn from this deplorable state of affairs was the reform of industrial society. Although colonial slavery was not yet abolished in the 1830 s, it was certainly morally discredited. The same cannot be said of industrial wage labor. The point of the analogy, therefore, was to argue not against slavery in the traditional sense but, rather, against the rapidly expanding wage slavery of the metropole. For those socialists pragmatically engaged with the realities of colonial slave emancipation, however, the analogy cut both ways. As much as they sympathized with the plight of the slaves, the perils so carefully outlined by those promoting industrial reform also suggested a frightful future for freedmen and freedwomen in postemancipation societies.

\section{Emancipation through Association}

Jump To Section...

The rhetoric of association was used throughout the 1830 s and 1840 s, both by the 
"utopians" of the Saint-Simonian and Fourierist movements and by the burgeoning workers' movement.77 Advocates argued that association could inhibit the return of Old Regime apprenticeships while curtailing the threat posed by the free market to prices and wages. Indeed, resistance to the laissez-faire policies of the Orleanist monarchy was a catalyst to France's earliest workers' organizations. 78 For figures such as Saint-Simon and Fourier and their disciples, association meant something far more ambitious, encompassing the wholesale restructuring of human sociability, including the elimination of "parasitic" merchants in favor of the direct connection of producers and consumers. 79 Moreover, in contrast with Marxist socialists of the next generation, romantic socialists sought to mitigate class conflict by buttressing mutual aid and cross-class cooperation. Although some workers' organizations saw Fourierist and Saint-Simonian forms of association as overly theoretical, hierarchical, and even paternalistic, for others it resonated deeply. $\underline{80}$ In the concept and practice of association, the Left in France developed a thoroughgoing critique of liberalism and individualism in both the economic and the social arenas.

Fourierist socialists were by far the most systematic proponents of association in the antislavery context. Although not uniform in their approach, Charles Fourier, Charles Dain, Désiré Laverdant, and Jules Lechevalier all suggested some form of cooperative labor association as the solution to the problem of slave emancipation. 81 For Dain, who cleaved to Fourier's views on the identity of slavery with life in the corrupt state of civilization, association was the foundation of a healthy society and thus the only possible answer to chattel slavery. His analysis offered an incisive critique of contemporary antislavery views and of liberalism in general. Laverdant and Lechevalier, more focused on plantation economics, both proposed forms of cooperative labor and land management between the planters and freedmen with varying degrees of autonomy and gain for the contributors. 82 Their objective was to avoid the foreseeable consequences of emancipation such as workforce instability, interracial violence, and mass dislocation among freedmen and freedwomen. Unlike either the colonial planters who shared these concerns or the previous generation of antislavery advocates, they anchored their discussions as much in the metropolitan 
dynamics discussed above as in the specific conditions of colonial economics.

The first of these associationist proposals came from Charles Dain in 1836, in his work De l'abolition de l'esclavage, which was published together with Fourier's brief essay "Remède aux divers esclavages." 83 Looking briefly at Fourier's work, we find much that foreshadows later proposals. Fourier's primary aim was to refute the British reparations plan, which he caustically called "the Wilberforce method, that our Anglomaniacs want to imitate." He argued instead that adopting "the art of association" was the way to end all forms of slavery in the world. In critiquing contemporary society, Fourier equated the worker and the slave- both specifically, by speaking of slavery and indigence in tandem and, more generally, in his repeated calculation of the total number of slaves in the world, a small proportion of which were found in the English and French colonies. 84 According to Fourier, association would remedy key issues facing modern society by making work attractive, putting discord and inequality to productive use, and providing satisfying material returns for everyone. 85

In notable contrast to the rights-based assumptions that guided liberal abolitionists of the era, Fourier denied the equality of individuals. Rather, he proposed to leverage the fundamental inequalities among people, a manifestation of his overarching observation that the tendency of human beings is to "remain such as nature has made them." To end the ubiquitous slavery that constituted modern life, those vices that conventional morality declared to be vicious - discord, inequality, and immoderate ambition-would have to be leveraged rather than squelched. 86 Redrawing society to optimize humankind's essential qualities would produce virtually limitless productivity and happiness. $\underline{87}$ Released from the ill-fitting suit of civilization, humanity would produce all that is necessary to become "happy and rich." $\underline{88}$

In Fourier's view, slave emancipation would entail remaking not only the plantation colonies but also all of human society. $\underline{89}$ In reformed society, humanity would be materially supplied, worries for the state of women and children obviated, and education "of all kinds and degrees" free. According to his logic, in a reformed 
world, "slaves could no longer exist, because combined domesticity [in the phalanstery] is a service infinitely better and less costly than that of slaves." 90 In eschewing reparation payments to slave owners, Fourier argued for what contextually was a radical abolitionist position; however, his analysis ultimately enfolded the institution of slavery within his larger reform agenda, deferring actual emancipation until after the wholesale remaking of society and ignoring the racial hierarchy. Also worth noting is what we do not find in Fourier's essay. His argument was not against the immorality of slavery per se; rather, it rested on the equation of all subject laborers, with little differentiation among the various categories of the oppressed. In the thoroughly corrupt era of "Civilization," as Fourier designated human development in his day, slavery was only a manifestation of a larger set of problems, not a key issue in itself. Fourier's premise is echoed and elaborated upon in the more pragmatic programs of those socialists who wrote specifically about ending colonial slavery, Charles Dain and Désiré Laverdant.

Whether coming from Île de France (Laverdant), Guadeloupe (Dain), or Martinique (Lechevalier), all of the antislavery, proassociation socialists under discussion here had firsthand knowledge of the realities of black slavery in the empire. Taking their associationist plans and their colonial origins as evidence of their suspect allegiance to antislavery, Victor Schœlcher was highly critical of both Dain and Lechevalier, although they present rather different cases upon closer examination. Schœlcher seems to have unjustly indicted Dain as "falsely abolitionist," suggesting that he was an "abolitionist who does not want abolition." His accusations that Lechevalier was "pretending to be a disciple of Saint-Simon and Fourier in order to enrich 'a few feudal barons," however, seem more justified.91Laverdant seems to have escaped Schœlcher's wrath. Nonetheless, these three authors' familial ties and firsthand experiences with slavery significantly informed their approaches and priorities regarding emancipation.

Factional politics of the July Monarchy aside, there is no contesting the ambiguities in these proposals for slave emancipation. Informed by what one historian 
of abolition calls Fourier's "confusion" about slavery, they become intelligible only if we consider the socialist agenda in its metropolitan context.92 Although both Dain and Laverdant were informed by Fourier's science sociale, their works differed significantly. Dain's discussion drew and expanded upon that of Fourier, similarly neglecting the racial issues involved in slavery. Laverdant, however, writing at the very eve of French emancipation, explained association in more detail and addressed race relations in his articles. His writings reflected the immediacy and tangibility of emancipation, and as a result his assessment of the contemporary racial dynamics was both more realistic and more problematic.

Taking his cue from Fourier's theory of the passions, Dain argued that "we" are social beings to the core and that we search "above all to determine our place" in the world.93 Privileging the social nature of man, Dain indicted previous-and especially British - approaches for failing to recognize the social dimension of the slavery problem.94 Dain's objections to the "political" emancipation of French slaves rested upon the same kind of skepticism of liberal rights-based approaches that Fourier voiced. He noted that, as with other social problems, "it is not enough for legislators to decree its abolition for it to disappear. ... Even when it seems to have disappeared on paper, it rules still in the world." $95 \mathrm{He}$ also denounced gradualist proposals that called for the moralization of the black population, averring that "in European society ... the grisette and the marquise both value their piece of gold, and in this society, much more than in the black population, bad morals, skulduggery, lying, injustice, treachery, violence, and cruelty reign." 96 Dain also questioned the underlying paternalism of the moralization agenda, arguing that it was the "disorder" of slavery that would cause the social disintegration so many feared, not the freeing of the slaves. Contemporary society had only to gain from their emancipation. $\underline{97}$

Rejecting liberal notions of capitalist freedom, Dain - again echoing Fourierargued that no one was really free in European society, neither "the child who dies in torture because he cannot run in the sunshine or breathe fresh air," nor the "young man for whom work is arid and science bitter," nor the entire category of woman. 
Dain sharply distinguished political and social change: "There exist two sorts of liberty, political liberty, which is declared and which we possess[,] ... and social liberty, which we do not yet possess." Posing the question, "Is abolition necessary?" he answered affirmatively, emphasizing the material condition of the freed, not just their status as free. 98 It is important to note, however, that Dain's social liberty encompassed not only the enslaved but also "those of us who remain human beings." Reflecting the socialist ideal of interdependence, he asserted that everyone in a slaveowning society feels its effects, as "the suffering of one member propagates by degrees among all other members." 99 Only through an integrated, associated emancipation of the entire human family could slavery be affirmatively ended.

In his 1836 treatise, De l'abolition de l'esclavage, Dain offered little concrete detail about how associated life would run, but in 1847 he observed that the Caribbean colonies were "admirably prepared: the workers are united by many ties; they only need to pull together more." 100 The end of chattel slavery would come with the arrival "throughout the globe of an era of social harmony" rather than through any specific abolition of colonial slavery. Enfolded in Fourier's "absolute" vision of human happiness, the eradication of black servitude in the colonies would accompany the realization of "human destiny," presumably near on the horizon.101 In this later text, Dain offered more detail as to what the future might hold: "To destroy the corporate bonds that unite slaves to masters and slaves to each other would be to destroy work in common, work founded on the convergence of individual efforts. ... The seed of association, ... for intelligent men of our epoch, is the sole base on which the new colonial establishment should be founded."102 By the late 1840s, Dain had seemingly moved into a more pragmatic mode, reflecting the heightened abolitionist consensus in the late 1840s, while relying still on the Fourierist belief in the necessity of making work attractive. Nevertheless, his proposal remains vague on the question of race. From the specific perspective of colonial slavery, it provokes several questions about association: How is one's nature defined - spiritually or biologically? Is race an element in the definition of one's nature? Does the old social order remain legible in the new? If, as Dain argued, the former masters are also "our brothers," how 
will race relations be regulated?

Désiré Laverdant was originally from Île de France, which had been taken from France by Great Britain in 1810.103 From the mid-1840s until 1848, he wrote about colonial questions for the Fourierist La Démocratie Pacifique. These articles were augmented and republished in early 1848 in Aux habitants de l'île Bourbon: La question coloniale. Laverdant was closer to the realities of colonial slavery both experientially and temporally than was Fourier or even Dain during these years (Dain returned to his native Guadeloupe in 1848), and his approach to slave emancipation reflects that proximity. 104 The proposal for association-based slave emancipation that he developed in his collection demonstrates how racial division strained association's unifying potential in the colonial context.

Although he lived most of his adult life in France, Laverdant's antiliberal views on abolition clearly drew as much on his colonial upbringing and on his experience as a lawyer on Mauritius in the years immediately after emancipation, 1836-40, as they did on Fourierism.105 Mauritius was subject to the emancipation decreed by the British in 1834 and the resultant imposition, in Laverdant's words, "of large-scale industrial feudalism." 106 As the main observer on colonial issues for La Démocratie Pacifique during the 1840s, Laverdant claimed the "rights of the French citizen" through representation for the colons and argued repeatedly that their cooperation would be integral to any successful emancipation. 107 Linking these rights to the abolition he consistently advocated, Laverdant asserted that "emancipation for the blacks is also emancipation for the whites; with the abolition of slavery and the organization of free labor there will begin, for the colonies, a new life of loyalty, dignity, and vigor." 108 Advocating both the end of slavery and preserved autonomy for the planters, Laverdant's proposal for association resisted the neat pro versus anti dichotomy of abolitionist rhetoric. In it he simultaneously critiqued the priorities of the colonists, rejected the fundaments of liberal antislavery, and proposed a third path in their stead. $\underline{109}$

Opening with a diatribe against the colonial delegate from Île Bourbon, M. Dejean 
de la Bâtie, whose ideas reflected the "old world," Laverdant's Aux habitants de l'île Bourbon looked to the progressive colons of Bourbon to lead the way out of slavery: "Let the dead bury their dead, and you, born of generous blood, rise up for a new life!" 110 Laverdant simultaneously defended the procolonial bona fides of Fourierism against attacks from the likes of slavery advocate de la Bâtie while attacking liberal antislavery proposals and deflecting the criticism of the mainstream press, especially the Journal des Débats. In 1847, while denouncing metropolitan domination of the colonies and demanding colonial representation, for example, he also asserted that the time had come "when the inhabitants of the islands must no longer invoke the worst of exceptions and defend the most malign of privileges, slavery." 111 Amid repeated assertions of his journal's "independence and ... disinterest," Laverdant held a tenuous position, both politically and ideologically. 112 His stated goal in this work was to fill the "systematic lacunae" in the arguments on both sides of the slavery debate, one that he characterized as "the old quarrel of the spirit and matter" and that he proposed to resolve by "embracing the question in a complex and integral manner." $\underline{113}$

In Laverdant's view, colonial society could not be reformed through the "imperfect, truncated" solutions offered by England and modeled on Mauritius. The English had, by Laverdant's lights, broken the "false and repressive regime that curbs the slave to work"; they had not, however, offered an affirmative alternative, one "harmonic, at once gentle and profitable for the worker and effective for production." Acknowledging the good intentions of the British, Laverdant rejected their approach to emancipation as incomplete because of their failure to grapple with the economic consequences of emancipation.114 Denouncing the blindness both of men of state and of the British "saints," he pointed to the economic condition of the former slaves and their former masters: "Now, is the question definitively resolved to allow the wealth to dissipate and the populations to regress toward the state of savagery?" 115 Insisting on a theme we have seen elsewhere, he asserted that work fulfills human destiny, enables the development of human intelligence, and ultimately reinforces "more and more the ties of fraternal association." From Laverdant's socialist perspective, a truly complete 
emancipation would have had to encompass both the material and the spiritual. This could be achieved only by the preservation of the productive capabilities of the colonies, rather than by their gradual degradation. Reflecting the intertwining of class and race in the colonial context, Laverdant argued: "When one invokes the interest of production, it must not be only to the profit of the colonist; ... the black population is also profoundly interested in the maintenance and growth of public wealth.... True liberty is dependent on ease, ... in a civilized society, indigence is the source and sign of servitude. Let us never forget, when we pursue some grand idea of liberty, that a close tie unites the material to the spiritual, and that the human soul will never be free and happy on an earth poorly cultivated and impoverished." $\underline{116}$

This mutually beneficial prosperity would depend on the labor of the black population, whether enslaved or free, and would be ensured through association, which would progressively bind together in unity the "grand human family." 117 English emancipation had stopped short of true reform and had reproduced the forces of disorder plaguing the metropole, "introducing the colonies into the state of insolidarity, fragmentation, antagonism, in its excessive individualism," which would ultimately produce only the slow decomposition of the "false" social ties of the colonies without building the positive "principles of association." $\underline{118}$

In his response in 1845 to the debates on the Mackau laws-attacking, in particular, Charles Forbes, comte de Montalembert, a forceful advocate of British-style emancipation-Laverdant evoked the specter of racial and class conflict, asserting that "the law just passed accords new rights to the slave; it has the effect ... of increasing the state of antagonism, defiance, and hostility between White and Black." 119 Laverdant argued that a "happy" emancipation could be effected only with the cooperation of the white planters and the colonial councils, factors discounted or eliminated in metropolitan proposals that worked at the expense of the planters. Treating colonial society in holistic terms, Laverdant called for the reconfiguration of existing ties between the races/classes in order to successfully emancipate the slaves, and he expressed doubts about the ability of "pure-blooded Creoles" to effect this 
change, looking instead toward the "progressive" elements of colonial society. Laverdant's doubts, however, were "gloriously" undone when the colonial counsel of Guadeloupe called for association-based emancipation in July 1847, largely in response to the Mackau laws. 120 The French government, abolitionists, and proslavery lobbyists alike rejected the Guadeloupe plan. Although historians disagree as to how "socialist" it really was, it is clear from Laverdant's writings in 1847 and 1848 that he saw it as an alternative to either liberal emancipation or the status quo.121 At the time, this position was seemingly confirmed by the energetic opposition of figures such as the baron Charles Dupin and Thomas Jollivet, the major spokesmen in Paris for the proslavery lobby.122 Moreover, the Guadeloupe proposal echoed positions that Laverdant had taken for the previous several years in the pages of La Démocratie Pacifique, as well as socialist fears of the kind of instability that had been caused by the Mackau laws: "The moral consequence will be that the colon, openly or silently, will fight against his slave, and destroy around him all sources of his savings [pécule]. This is a relentless and odious war that you would create where the task is to extinguish divisions and to organize harmony." 123

In another article published in 1845, Laverdant gave a rough outline of the society he imagined: employing the technological innovations of one M. Paul Daubrée, a planter, the association he envisioned would establish a central factory for sugar production, bringing together the white, the "small Creole," and the black, thereby preventing the "organization of collective slavery that would follow from industrial feudalism." 124 An association of this form, moreover, would avoid the benighted fate of the French planters on Mauritius who had been driven into bankruptcy by the 1834 British emancipation and preyed upon by the bankers and commissioners. 125 The economic system Laverdant proposed would thus stabilize the workforce, which would be constituted both by the "shareholders" who had been slaves and by a flood of immigrant workers from the metropole. Building model farms and rural schools with the economic support that the government would provide to the association in lieu of direct reparations, such an organization would form the "germ of an excellent transformation of colonial society." 126 Further detail can be gleaned from 
the Guadeloupe plan, which would have ensured compulsory labor at the rate fixed by the 1845 Mackau laws, provided for minimal economic independence for former slaves, and proposed the unequal distribution of proceeds between workers and "masters." 127 The plan would have allowed newly freed workers to leave their masters after six years-but only if they "associated" themselves with a new master and received consent from the old one. This system would have continued until such a time as "the habits of work are sufficiently instilled" and the "moral state of the colonial population is advanced enough," or until the recruiting of free workers had ensured a steady labor supply. The system was reminiscent in many ways of the emancipation instituted in Haiti prior to independence and, likewise, bore similarities to the British apprenticeship system, although neither Laverdant nor the Guadeloupe assembly referenced the historical precedents in their discussions. $\underline{128}$

Although Laverdant deemed the bond between the slave owner and the slave "false" under the slavery regime, the association system he described would have maintained key aspects of the racial hierarchy that were deeply embedded in the colonial order. According to Laverdant, the black race was the "man-child," "little able to manage himself and educate himself," and thus in need of tutelage to "come out of the savage state and of servitude, where he has been brutalized, degraded, and corrupted." Education and religious instruction, the "moralization" so frequently discussed by gradualist abolitionists throughout the nineteenth century, would be the means by which the "infantile" black race would "mature for work, for liberty and for happiness." And what would be the source of this tutelage? The white race-although Laverdant deemed its spirit "turbulent and confused" and saw it, too, as childlike. Nonetheless, he maintained that it was easy to "distinguish in the black race of Africa the signs of an age even less advanced[;] ... the African is a child of three or four years" and thus in need of guidance and education in order to be encouraged to work. Laverdant recognized the potential for abuse that existed in such a patronage system, however, and asserted that "the slave must have recourse to a higher authority than his master" in the form of collective patronage. $129 \mathrm{He}$ thus proposed a regional 
tutelage system that would provide for the collective supervision of blacks by whites.

Laverdant's plan echoes the Southern exceptionalism that proslavery advocates in the United States proclaimed during the same period and afterward, according to which a special familial bond existed between masters and slaves, a bond supposedly ill-understood by Americans in the industrial "free" North.130 Laverdant similarly evoked this colonial "family" in opposition to the metropolitan financiers and "European philanthropists, moralists, and legislators" who saw "the state of the proletariat" as normal and the principle of "anarchic laissez-faire" as just. $131 \mathrm{~A}$ paternal order would preserve the familial bond at the heart of colonial society that had been perverted by the brutality of the slave system. Laverdant thus implored the colons of Bourbon to associate in order to avoid social disintegration. It was their task to lead colonial society toward a prosperous postemancipation future, "escaping the exploitation of financiers and tradesmen of the metropole." In this paternalist order, the dangers of class conflict - abhorrent to socialists in the metropole-would also be alleviated. By preserving and strengthening the familial ties that they had with "their" black population, the colons would "avenge" themselves "gloriously" on "the wicked liberals of Europe." 132

According to Laverdant, association would work for the benefit of both the white Creole and the black populations. In his discussion of the economic terms of association, however, its unsavory realities become increasingly evident as pragmatic reality intervened: with the goal of "prevent[ing] the dispossession of old Creole families to the profit of the feudalism of money," emancipation would of necessity preserve access to labor and ensure the sanctity of private property.133 In Laverdant's new social order, then, the principles of hierarchy and the useful deployment of human inequality would be central, echoing Fourier and Dain. Questions implicitly raised by Dain's discussion-What is the role of race in determining one's nature and thus one's place? Will the "old" order be legible in the new one? - return here, but with far more sinister implications, given the tutelage model of race relations that Laverdant proposed and his emphasis on the stability of labor: "It is not enough that 
each colonist be the tutor and the protector of his freedmen and of his slaves; it is necessary that all of the white race, represented by the most worthy, be the tutor and the protector of the black race." 134 Although in many ways persuasive in his rejection of the existing slavery regime, Laverdant's critique of liberal individualism, refracted through his objection to British emancipation and his alternative proposals for association, was compromised by the reinvigorated racial hierarchy of his promised postemancipation colonial order.

Given that romantic socialists believed that the autonomous individual was, in essence, a liberal fiction, the model of emancipation that these authors offered was, not surprisingly, contradictory to the modern notions of freedom upon which enfranchised citizenship is built. Laverdant's intervention, in particular, illuminated the uncomfortable gray zone between liberal individualism and communitarian dependence, a gray zone that perhaps inevitably became colored by the racial politics of the colonies both before and after emancipation. Yet socialist concerns for the consequences of unfettered independence simultaneously echoed fears about social cohesion and fragmentation that were endemic at the time among socialists in modernizing France. Thus while other historians and some contemporaries have interpreted socialist plans as primarily aimed at undermining emancipation, my contextualized reading of their proposals suggests that their main objection was to the supposed benefits of liberal emancipation and that their concerns were deeply influenced by metropolitan developments shaping socialism. Clearly, French socialists, like their liberal antagonists, were ambivalent about upending the racial hierarchy that had justified slavery. Even the most "confused" among them, however, were proposing a sweeping indictment of both colonial slavery and modern society in crafting these proposals - an indictment that reflected their fundamental discomfort with the atomization through which they experienced modernity-and were seeking alternative, albeit problematic, ways to move from servitude to freedom.

\section{Conclusion}

Jump To Section... 
In no small part because of their pragmatism, the proposals for associationist slave emancipation that I have described here are difficult to reconcile with socialist humanitarianism in the early nineteenth century. Based on a notion of human nature and societal organization that privileged connectedness and stability over individual autonomy, these proposals constrained individual liberty and, along the way, reinforced the racial hierarchy upon which the old slave system had been built. Furthermore, in their pervasive view of slavery as analogous to the condition of the industrial working classes, socialists idealized a paternalist notion of social dependency and obfuscated the violence and degradation that lay at the heart of the slavery regime. Yet the nonliberal social order that socialists envisioned in fact bears a far greater resemblance to the reality of the postemancipation colonies than we might expect if we read only their liberal contemporaries. Reflecting both the instability of the colonial economy in the first part of the nineteenth century and the fast and brittle process of modernization in Europe, these associationist emancipation plans offer us new insight into the anxieties that were aroused by both colonial and metropolitan social changes and help us understand socialists' interpretation of the transition to modernity. Socialist concerns with wage labor in the metropole set them at odds with the underlying assumptions of liberal emancipation, neatly encapsulated in the decree of April 27, 1848, that abolished slavery: "The principle that French soil frees the slave who touches it is applied to the colonies and possessions of the Republic." The industrial workers who lived on that French soil were anything but free, in socialists' eyes, and they were far from desiring the same status for the newly freed populations of the colonies.

In fact, many of the problems of free labor and social stability that figures such as Dain and Laverdant anticipated did prove to be obstacles to the full extension of individual liberty and full citizenship in the former slave colonies of the empire. According to the terms of the 1848 emancipation decree, former male slaves of the French colonies became citizens of the Second Republic and remained, under the Second Empire and beyond, nominally legal equals to metropolitan Frenchmen by the terms of universal manhood suffrage. During the brief Second Republic (1848-51), 
Guadeloupe and Martinique saw vigorously contested electoral campaigns for the National Assembly, even while chaos surrounded the organization of labor and compensation. 135 This situation echoed contemporary events in France, where the votes of newly enfranchised workers and peasants dramatically influenced the politics of the Republic and where social unrest driven by economic need led to repressive measures on the part of the centralized authority of the French empire. June 1848 saw brutal street fighting between workers and the republican authorities sparked by the abolition of the national workshops. The "June days" witnessed the violent repression of organized workers in France and the sentencing of thousands to colonial transportation; the threat of similar violence was felt in the newly enfranchised colonies as well. Nelly Schmidt notes that the political "effervescence" of these years is often evident in the decisions made by colonial administrators in the economic and social realms, suggesting the fine line between "measures intended to maintain public order troubled by political events" and "initiatives taken by local powers to control the professional activities of the 'newly free' off the plantations." 136

Given this social and political reality, it is not all that surprising that the 1848 decree and subsequent administrative directives entailed significant constraints on both the economic freedom and the mobility of freedmen and freedwomenconstraints designed, like previous measures, to maintain the labor supply on the plantations. 137 Property and wealth remained under white control, and to this day the class structure of the French overseas departments reflects the racial order of slavery. $\underline{138}$ Prohibitions against vagabondage, limitations on land use and purchase, taxes on education, and laws requiring those over the age of ten to work regularly were enacted during the decade immediately following emancipation.139 In his October 1848 decrees, Commissioner Sarda Garriga, sent by the republican government to La Réunion (formerly Bourbon) to promulgate the April decree, noted that "work is obligatory for all" and issued the following caution to the soon-to-be-freed: "Listen to my voice, my counsel, I who have been given the noble mission of initiating you into liberty. ... If, [when you] become free, you remain at work, I will love you; France will protect you. If you desert it, I will withdraw my affection; France will abandon 
you like bad children." 140 Garriga's decree of October 24 made work obligatory even after the legal emancipation set for December, an obvious concession to the labor needs of the colonial landowners. In terms of the ideal of the liberal individual, the "newly freed" populations were hardly liberated in any absolute sense in 1848, and the problems anticipated by romantic socialists were far from resolved at emancipation. 141 Starting with the 1848 commission on abolition and continuing with a variety of colonial commissions through the beginning of the Second Empire, mechanisms of social control aimed at constraining or even suppressing the political expression of the new citizens were elaborated from the metropole. 142

Equally important in the long run is the reality that the coveted freedom granted by the 1848 revolutionaries was doubly "assassinated" by the terms of emancipation and by the persistence of centralized governance of the French empire.143 On the one hand, as Laverdant and Dain would have predicted, former slaves found themselves economically abandoned by the new social order: consigned to wage work, cut off from seed capital, and inhibited in both educational advancement and political expression, they were hamstrung and continued to live in conditions of dependence and poverty closely akin, as contemporaries acknowledged, to slavery.144Although they were legally citizens, the populations of the former slave colonies were subject to the strictures of colonial governance through the second third of the nineteenth century, limiting economic and political autonomy both for the citizens and for the colonies themselves. 145 In many ways, we can see here a recurrence of the contradictions of the first era of emancipation. Like the former slaves of 1794, the slaves of 1848 were "freed but forced to keep working." 146 Modern for their invocation of individual rights as well as for the racism that continued to structure postemancipation society, "liberal" slave emancipations in both the 1790 s and the 1840s in fact prioritized labor supply and property rights at the expense of those emancipated. The expectations of liberal abolitionists were fulfilled, in that slavery was legally ended in these instances-but so were the expectations of their nonliberal contemporaries, the romantic socialists, in that former slaves did not become the equals of their fellow French citizens nor were they fully incorporated into the 
political, social, or cultural life of the empire.

The critique of liberal modernity made by romantic socialists in their proposals for slave emancipation offers us an important angle from which to assess the transition under way in society both in France and in the French colonies during these years. The "new" empire being built in Algeria amid the dismantling of the "old" one was predicated upon significantly altered justifications. In particular, free trade and freesettler labor were privileged, as was the pursuit of the so-called civilizing mission. In notable contrast to the unfree system of the old empire, the new order being built in Algeria depended upon the migration of European colonists for its economic viability. 147 In redefining its priorities and structures, the new imperialism removed from the heart of French society the moral quandary of slave ownership and resituated questions of violence and oppression, at least temporarily, to the periphery of the metropolitan conscience. However, in the former slave colonies of the empire, the legacy of slavery continued to shape the lived reality of the "newly free" both socially and economically. Seen in this light, socialist alternatives to liberal emancipation appear to be prescient commentaries on the difficulties of happiness and contentment, let alone freedom, after the end of slavery.

\section{Notes}

- * I would like to thank Jonathan Beecher, Michelle Burnham, Katharine Hamerton, Rachel Nuñez, Jennifer Sessions, and the anonymous reviewers for the Journal of Modern History for their knowledgeable critiques of this article. Matthew Newsom Kerr and Amy Randall read multiple drafts and contributed greatly to the clarity of my argument. I would also like to thank members of the Santa Clara University History Department Colloquium who read and discussed an early draft of this paper, in particular Jerry McKevitt and Nancy Unger, who were generous with their editorial comments.

- 1 Désiré Laverdant, Aux habitants de l'île Bourbon: La question coloniale (Paris, 1848), 41; emphasis added.

- $\quad 2$ For the connections between imperial policy and slave emancipation in France, see Jennifer E. Sessions, By Sword and Plow: France and the Conquest of Algeria (Ithaca, NY, 2011); Jennifer Pitts, A Turn to Empire (Princeton, NJ, 2005); and Sankar Muthu, Enlightenment against Empire (Princeton, NJ, 2005). On the British context, see Christopher Leslie Brown, Moral Capital: Foundations of British Abolitionism (Chapel Hill, NC, 2006); and Deirdre Coleman, Romantic Colonization and British Anti-slavery 
(Cambridge, 2005).

- $\quad 3$ Michael Löwy and Robert Sayre, Romanticism against the Tide of Modernity, trans. Catherine Porter (Durham, NC, 2001); Zvi Ben-Dor Benite, "Modernity: The Sphinx and the Historian," American Historical Review 116, no. 3 (June 2011): 638.

- $\quad \underline{4}$ The notion of alternative modernity has most often been used to refer to (post-) colonial contexts and to describe deviations from the progressive, modernizing, capitalist narrative of individual freedom integral to Western historiography. Sibylle Fischer uses the phrase to discuss the denial of the Haitian Revolution in Modernity Disavowed: Haiti and the Cultures of Slavery in the Age of Revolution(Durham, NC, 2004), 146. Mimi Sheller writes of the "counter-narrative to modernity" that was a component of the Haitian and Jamaican postslavery ideology of freedom; see Mimi Sheller, Democracy after Slavery: Black Publics and Peasant Radicalism in Haiti and Jamaica (Gainesville, FL, 2000), 5. See also Osama W. Abi-Mershed, Apostles of Modernity: Saint-Simonians and the Civilizing Mission in Algeria (Stanford, CA, 2010), 8. For a critique of the notion of plural modernities, see Frederick Cooper, Colonialism in Question (Berkeley, 2005), 113-49. For a wide-ranging discussion of the utility of the category of modernity for historians, see the roundtable "Historians and the Question of 'Modernity,", American Historical Review 116, no. 3 (June 2011): 631-751.

- $\quad 5$ Seymour Drescher argues that eighteenth-century rhetoric saw the erasure of the middling category of "unfree," while the 1830s and 1840s saw its return. Seymour Drescher, "Abolition Expectations: Britain," in After Slavery: Emancipation and Its Discontents, ed. Howard Temperley (London, 2000), 60-61.

- $\quad 6$ During the July Monarchy, there were approximately 270,000 slaves in the French colonies of Guadeloupe, Martinique, Bourbon, and Guiana. Lawrence C. Jennings, French Anti-slavery: The Movement for the Abolition of Slavery in France, 1802-1848 (Cambridge, 2000). On the "first" and "second" abolitions, see Marcel Dorigny, ed., The Abolitions of Slavery: From Légér Felicité Sonthonax to Victor Scholcher, 1793, 1794, 1848 (New York, 2003).

- $\quad$ I Alexis de Tocqueville, Writings on Empire and Slavery, ed. and trans. Jennifer Pitts (Baltimore, 2001), 199.

- $\quad$ 8 Dain's letter was published originally in La Démocratie Pacifique, March 20, 1847; it was reprinted in Nelly Schmidt, Abolitionnistes de l'esclavage et reformateurs des colonies (Paris, 2000), 205.

- $\quad 9$ Seymour Drescher and Frank McGlynn date the emergence of this scholarship to the 1980s; see Seymour Drescher and Frank McGlynn, eds., The Meaning of Freedom: Economics, Politics, and Culture after Slavery, Pitt Latin American Series (Pittsburgh, 1992), 4. The English-speaking Atlantic world, particularly the United States, has generated an enormous literature (too vast to inventory here). For transnational and French contexts, see, among others, Frederick Cooper, Thomas Holt, and Rebecca Scott, Beyond Slavery: Explorations of Race, Labor, and Citizenship in Postemancipation Societies(Chapel Hill, NC, 2000); Pamela Scully and Diana Paton, eds., Gender and Slave Emancipation in the Atlantic World (Durham, NC, 2005); Sheller, Democracy after Slavery; Nelly Schmidt, La France: A-t'elle aboli l'esclavage? Guadeloupe, Martinique, Guyane, 1830-1935 (Paris, 2009); and Oruno D. Lara, Suffrage universel et 
colonisation, 1848-1852 (Paris, 2007), and La liberté assassinée: Guadeloupe, Guyane, Martinique, et la Réunion en 1848-1856 (Paris, 2005), as well as La colonisation aussi est un crime: De la destruction du système esclavagiste à la reconstruction coloniale (Paris, 2005).

- 10 Lara rejects the terminology of abolition entirely, arguing that "the process of destroying the slave system" more accurately represents the ongoing experience of these societies. Oruno Lara, Les Caraïbes(Paris, 1986); and see Drescher and McGlynn, The Meaning of Freedom, 4. See also discussions in Howard Temperley, ed., After Slavery: Emancipation and Its Discontents (London, 2000), 1; and in Thomas C. Holt, The Problem of Freedom: Race, Labor, and Politics in Jamaica and Britain, 1832-1938 (Baltimore, 1992).

- $\quad 11$ Seymour Drescher, The Mighty Experiment: Free Labor versus Slavery in British Emancipation (New York, 2002), 107-8; Peter Emmer, "The Price of Freedom: The Constraints of Change in Postemancipation America," in Drescher and McGlynn, The Meaning of Freedom, 24; writing three years after emancipation, Benjamin Laroche made a similar point. Benjamin Laroche, Histoire de l'abolition de l'esclavage dans les colonies françaises (Paris, 1851), 9.

- $\quad 12$ Christopher L. Miller, The French Atlantic Triangle: Literature and Culture of the Slave Trade(Durham, NC, 2008), 70. A telling illustration of this narcissism is the French hesitation to interfere with the slave trade in colonial Algeria, then in the hands of non-Europeans. Benjamin Claude Brower,A Desert Named Peace: The Violence of France's Empire in the Algerian Sahara, 1844-1902 (New York, 2009), 159-79. For a devastating assessment of the self-congratulatory core of antislavery narratives, see Marcus Wood, The Horrible Gift of Freedom: Atlantic Slavery and the Representation of Emancipation (Athens, GA, 2010).

- $\quad 13$ Drescher and McGlynn, The Meaning of Freedom, 21; on the shortcomings of compensation for slave owners, see Nicholas Draper, The Price of Emancipation: SlaveOwnership, Compensation, and British Society at the End of Slavery (Cambridge, 2010), 271.

- $\quad 14$ On postrevolutionary French intellectual and social life, see Jan Goldstein, The PostRevolutionary Self: Politics and Psyche in France, 1750-1850 (Cambridge, MA, 2005); and Denise Z. Davidson,France after Revolution: Urban Life, Gender, and the New Social Order (Cambridge, MA, 2007). On changing economic perspectives, see Victoria E. Thompson, The Virtuous Marketplace: Women and Men, Money and Politics in Paris, 1830-1870 (Baltimore, 2000), 1-14; and Elizabeth Marie Sage, A Dubious Science: Political Economy and the Social Question in Nineteenth-Century France (New York, 2009).

- 15 Myriam Cottias calls the slave revolt on Saint Domingue the "narcissistic wound of French colonialism." Myriam Cottias, ed., D'une abolition, l'autre: Anthologie raisonnée de textes consacrés à la seconde abolition de l'esclavage dans les colonies françaises (Marseille, 1998), 7. On the metropolitan context, particularly the silk worker (canut) uprisings in Lyon in 1831 and 1834, see Jeremy D. Popkin, Press, Revolution, and Social Identities in France, 1830-1835 (University Park, PA, 2002); Robert J. Bezucha, The Lyon Uprising of 1834: Social and Political Conflict in the Early July 
Monarchy (Cambridge, MA, 1974); and Ludovic Frobert, Les canuts; ou, La démocratie turbulente: Lyon, 1831-1834 (Lyon, 2009). On slave revolts, see Rebecca Hartkopf Schloss, Sweet Liberty: The Final Days of Slavery in Martinique (Philadelphia, 2009), 91, and "The February 1831 Slave Uprising in Martinique and the Policing of White Identity," French Historical Studies 30, no. 2 (April 2007): 203-36; and Dale Tomich, "Liberté ou Mort: Republicanism and Slave Revolt in Martinique, February, 1831," History Workshop Journal 29 (Spring 1990): 85-91. For the linkage between canuts and colonial slaves, see Cottias, D'une abolition, l'autre, 6.

- $\quad 16$ The presence of significant numbers of colonial Frenchmen in the ranks of early socialism and the influence their worldview had upon the formation of socialism itself has yet to be explored by historians, but I will address it in future work.

- $\quad 17$ Such critiques have come in two forms and revolve primarily around Fourierism and the figure Jules Lechevalier, in particular. First, there are questions as to the bona fides of associationist antislavery; see Lawrence C. Jennings, "Slavery and the Venality of the July Monarchy Press," French Historical Studies17, no. 4 (Autumn 1992): 957-78, and "French Slave Liberation and 'Socialism': Projects for 'Association' in Guadeloupe, 1845-48," Slavery \& Abolition 17, no. 2 (1996): 93-111. Second, historians are divided as to the proper interpretation of Lechevalier's associationist plan for slave emancipation in Guiana, debating whether it should be seen as an impractical utopian strategy or as a ruse to maintain the essence of the slavery system; see Jennings, "Associative Socialism and Slave Emancipation in French Guiana, 1839-1848," Revue Française d'Histoire d'Outre Mer 88, nos. 330-31 (2001): 167-88; and Jack Hayward, "From Utopian Socialism, via Abolitionism to the Colonisation of French Guiana: Jules Lechevalier's West Indian Fiasco, 1833-1844," in De la traite à l'esclavage: Actes du colloque international sur la traite des noirs, ed. Serge Daget, 2 vols. (Nantes, 1985), 603-26. Lechevalier's biographer Olivier Chaïbi situates Lechevalier's Guiana program in the broader context of his evolving political and economic views; see Olivier Chaïbi, Jules Lechevalier, pionnier de l'économie sociale (Paris, 2009). Despite similarities to Lechevalier's plan, Laverdant's plan (discussed below) has received scant attention save in Cottias, D'une abolition, l'autre, 184-93; and passing mention in Schmidt, Abolitionnistes de l'esclavage, 272. Seymour Drescher refers to "socialists with colonial links" in "British Way, French Way: Opinion Building and Revolution in the Second French Slave Emancipation," American Historical Review 96, no. 3 (June 1991): 70934 , quote on 727 .

- $\quad 18$ British abolition witnessed a number of "experimental alternatives" that in practice challenged this divide as well. See Drescher, The Mighty Experiment, 106-20; Michael J. Turner, "The Limits of Abolition: Government, Saints, and the 'African Question,' c. 1780-1820," English Historical Review112, no. 446 (April 1997): 319-57; Brown, Moral Capital, 209-58; and Thomas Holt, "The Essence of the Contract," in Cooper, Holt, and Scott, Beyond Slavery, 33-59.

- $\quad 19$ Eugene Genovese describes strikingly similar responses to "progress" on the part of proslavery Southerners in America, observing that although they favored the "emergence of economic freedom," they also "repeatedly condemned the severing of the lord-serf relation and the withdrawal of support and protection from the laboring masses" that characterized the end of the Middle Ages. Eugene Genovese,The Slaveholders' Dilemma 
(Columbia, SC, 1992), 6. The proslavery advocate George Fitzhugh used similar language in his Sociology for the South; or, The Failure of Free Society (Richmond, VA, 1854).

- 20 Naomi J. Andrews, “'The Universal Alliance of All Peoples': Romantic Socialists, the Human Family, and the Defense of Empire during the July Monarchy, 1830-1848," French Historical Studies34, no. 3 (2011): 473-502.

- $\quad 21$ Louis Blanc, "De l'abolition de l'esclavage aux colonies," La Revue du Progrès, 1, no. 2, série (1840): 3-17, quote on 16.

- $\quad \underline{22}$ Flora Tristan, Pierre Leroux, Constantin Pecqueur, Alphonse Esquiros, Abbé Alphonse Constant, and Jeanne Deroin, among others, used the slavery analogy for marriage. For a discussion of the origins of this analogy, see Karen Offen, "How (and Why) the Analogy of Marriage with Slavery Provided the Springboard for Women's Rights Demands in France, 1640-1848," in Women's Rights and Transatlantic Antislavery in the Era of Emancipation, ed. Kathryn Kish Sklar and James Brewer Stewart (New Haven, CT, 2007), 57-81.

- 23 Laurent Dubois, A Colony of Citizens: Revolution and Slave Emancipation in the French Caribbean, 1787-1804 (Williamsburg, VA, 2004), 3.

- $\quad 24$ Polverel's approach in Haiti's southern province resembles socialists' programs. On Polverol'ssystème portionnaire, see Carolyn E. Fick, The Making of Haiti (Knoxville, TN, 1990), 168-73. Also worth noting is that communal ownership of land and distribution of rewards were proposed in the eighteenth century, as Florence Gauthier and Jeremy Popkin have discussed, although apparently no implementation was attempted. See Florence Gauthier, Périssent les colonies plutôt qu'un principe! Contribution à l'histoire de l'abolition de l'esclavage (Paris, 2002), 105-7; and Jeremy D. Popkin, You Are All Free: The Haitian Revolution and the Abolition of Slavery (Cambridge, 2010), 270.

- $\quad \underline{25}$ Laurent Dubois, "Avenging America: The Politics of Violence in the Haitian Revolution," in The World of the Haitian Revolution, ed. David Patrick Geggus and Norman Fiering (Bloomington, IN, 2009), 119-20; Sabine Manigat, "Le régime de Toussaint Louverture en 1801: Un modèle, une exception," in 1802: Rétablissement de l'esclavage dans les colonies françaises, ed. Yves Bénot and Marcel Dorigny (Paris, 2003), 109-26.

- 26 Scholars have recently debated the quality of French reactions to the Haitian Revolution. Michel-Rolph Trouillot's argument for the unthinkability of the revolution has been nuanced by Sibylle Fischer's Foucauldian diagnosis, in which denial is discursively productive, an assertion attested to by literary scholarship of the period: Fischer, Modernity Disavowed; Michel-Rolph Trouillot, Silencing the Past: Power and the Production of History (Boston, 1997). For a useful analysis of Restoration liberal antislavery through this lens, see Yun Kyoung Kwon, "When Parisian Liberals Spoke for Haiti: French Antislavery Discourses on Haiti under the Restoration, 1814-30," Atlantic Studies 8, no. 3 (September 2011): 317-41. Literary representations of slave revolts abounded during the Restoration and July Monarchy; see Miller, The French Atlantic Triangle. Primary sources include Marceline Desbordes-Valmore, Sarah (Paris, 1821); Victor Hugo, Bug-Jargal (Paris, 1826); Charles de Rémusat, The Saint- 
Domingue Plantation; or, The Insurrection, ed. Norman R. Shapiro, trans. Doris Y. Kadish (Baton Rouge, LA, 2008); Victor Séjour, "Le mulâtre," La Revue des Colonies (1837); Antony Thouret,Toussaint le mulâtre (Paris, 1834); Alexandre Dumas, Georges (Paris, 1845); and Eugène Sue, Atar-Gull (Paris, 1845).

- $\quad 27$ Kwon, "When Parisian Liberals Spoke for Haiti," 324-25; on Boyer's code rurale, see Alex Dupuy,Haiti in the World Economy: Class, Race, and Underdevelopment since 1700 (Boulder, CO, 1989), 95.

- $\quad 28$ Drescher, "British Way, French Way," 710.

- 29 Thomas Bender, The Anti-slavery Debates: Capitalism and Abolitionism as a Problem in Historical Interpretation (Ithaca, NY, 1992).

- 30 Emma Rothschild, Economic Sentiments: Adam Smith, Condorcet, and the Enlightenment(Cambridge, MA, 2001), 105-7.

- 31 Lawrence C. Jennings, French Reaction to British Slave Emancipation (Baton Rouge, LA, 1988), 35, 40, and "Réflexions d'un observateur sur l'émancipation des esclaves britanniques a l'île Maurice," La Revue d'Histoire Moderne et Contemporaine 29, no. 3 (1982): 467.

- 32 Most of the information available to the French public on British apprenticeship came from eyewitnesses sent to the British colonies; slave owners, including refugees from Saint Domingue, were often among these informants. Jennings, French Reaction, 35.

- $\quad \underline{33}$ Ibid., 210.

- 34 Liberals in the opposition during the Restoration were the main antislavery advocates. Germaine de Staël, her de Broglie relatives, and her intimate Benjamin Constant had close ties to British antislavery. Jennings, French Anti-slavery, 5-6.

- $\quad 35$ Drescher, "British Way, French Way." According to Jennings, the Société Française pour l'Abolition de l'Esclavage never had more than about one hundred adherents. Jennings, French Anti-slavery, 55.

- $\quad \underline{6}$ Jennings, French Anti-slavery, 187.

- 37 Paul Michael Kielstra, The Politics of Slave Trade Suppression in Britain and France, 1814-1848: Diplomacy, Morality, and Economics (New York, 2000).

- $\quad 38$ Despite his own gradualist tendencies, Tocqueville was particularly biting about Guizot's opportunism. See Tocqueville, Writings on Empire and Slavery, 225-26.

- $\quad 39$ See, e.g., Jules Lechevalier, Rapport sur les questions coloniales, adressé à M. le duc de Broglie, président de la Commission coloniale à la suite d'un voyage fait aux Antilles et aux Guyanes, pendant les années 1838 et 1839: Documents et pièces justificatives, 2 vols. (Paris, 1844).

- $\quad 40$ Jennings, French Anti-slavery, 146-50. Isambert saw Louis Philippe as the primary impediment to emancipation.

- $\quad 41$ Nelly Schmidt, Victor Scholcher et l'abolition de l'esclavage ([Paris], 1994); Anne Girollet, Victor Scholcher, abolitionniste et républicain: Approche juridique et politique de l'oeuvre d'un fondateur de la République (Paris, 2000). Schœlcher has long been 
heroized in the scholarship on French abolition. For a critique of this view and a corrective, see Lara, La liberté assassinée, 15-18; and Wood, The Horrible Gift of Freedom, 17-19. Schœlcher published in La Revue Encyclopédique when the socialists Pierre Leroux and Hippolyte Carnot were editing the journal in the early 1830s.

- $\quad 42$ Most explosive was Schœlcher's press war with Cyrille Bissette, the homme de couleur from Martinique who published La Revue des Colonies from 1834 to 1843. Bissette was also a proponent of immediate emancipation and vied with Schœlcher for political leadership in Martinique during the Second Republic. See Lawrence C. Jennings, "Cyrille Bissette, Radical Black French Abolitionist,"French History 9, no. 1 (1995): 48-66.

- $\quad 43$ Jennings, French Anti-slavery, 66; Francis Arzalier, "Changes in Colonial Ideology in France before 1848: From Slavery to Abolition," in Dorigny, Abolitions of Slavery, 261-71.

- $\quad 44$ Seymour Drescher, Dilemmas of Democracy (Pittsburgh, 1968), 162. See, e.g., Jennings's account of debate on the Mackau law and the responses of Agenor de Gasparin and Alexandre Ledru-Rollin to the issue: Jennings, French Anti-slavery, 217.

- $\quad 45$ La Réforme had a number of socialist contributors, including Louis Blanc. George Weill, Histoire du parti républicain, 1814-1870 (Paris, 1928), 139-54. William H. Sewell has shown that republicanism in the early 1830 s came to encompass economic and social issues, in part through the influence of organized workingmen active in republican organizations, particularly the Société des Droits de l'Homme. See Sewell, Work and Revolution in France: The Language of Labor from the Old Regime to 1848 (Cambridge, 1980), 208-10.

- $\quad 46$ Jennings, French Anti-slavery, 56-58. Carnot is an exception; see Robert Carlisle, The Proffered Crown (Baltimore, 1987), 173.

- $\quad 47$ Gareth Stedman Jones, "Saint Simon and the Socialist Critique of Political Economy," in La France et l'Angleterre au XIXe siècle: Echanges, representations, comparaisons, ed. Sylvie Aprile and Fabrice Bensimon (Paris: 2006), 44; Sage, A Dubious Science. Political liberalism was hardly hegemonic in France. In economic terms, British ideologies resonated with what Andrew Jainchill calls the "rationalist liberalism" of Guizot and the doctrinaires. Andrew Jainchill, Reimagining Politics after the Terror: The Republican Origins of French Liberalism (Ithaca, NY, 2008), 302. On the nineteenth-century reception of laissez-faire ideas in France and their ideological incompatibility with French political culture, see Jennifer Ann Greenfield, "Construing the Social Economy: The Reception of Free-Market Liberalism in France, 18401890" (PhD diss., Columbia University, 1997).

- $\quad 48$ On Say’s influence, see H. A. C. Collingham, The July Monarchy: A Political History

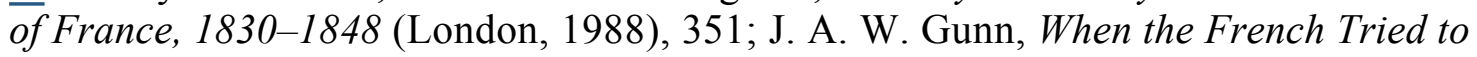
Be British: Party, Opposition, and the Quest for Civil Disagreement, 1814-1848 (Montreal, 2009); Pierre Rosanvallon, Le Moment Guizot (Paris, 1985); and Evelyn L. Forget, The Social Economics of Jean-Baptiste Say: Markets and Virtue (London, 1999).

- $\quad 49$ Etienne Cabet, Révolution de 1830 et situation présente, 2nd ed., 2 vols. (Paris, 
1833), 209.

- $\quad 50$ Charles Fourier, "Remède aux divers esclavages," in Charles Dain, De l'abolition de l'esclavage, suivi d'un article de M. Fourier (Paris, 1836), 44. Fourier's essay is bound in one volume with Dain's De l'abolition de l'esclavage and appears in that volume on pp. 43-54. It is cited there as "extrait du 5e $\mathrm{n}^{\circ}$ de La Phalange." La Phalange: Journal de la Science Sociale ran initially as a biweekly (variable) from July 1836 through July 1843 and then, again, from January 1845 through December 1849 as a monthly with a modified subtitle, Revue de la Science Sociale.

- $\quad 51$ Blanc, "De l'abolition de l'esclavage," 13-14.

- $\quad 52$ Montesquieu, The Spirit of the Laws (1748), bk. 15. Christopher Miller suggests that Montesquieu's stance "banished" slavery from Europe "while justifying [slavery's] existence" in Africa and the colonies. Miller, The French Atlantic Triangle, 66; on Rousseau, see 69. For a divergent view, see Madeleine Dobie, Trading Places: Colonization and Slavery in Eighteenth-Century French Culture(Ithaca, NY, 2010), 132.

- $\quad 53$ On the contradictions between thought and practice in Enlightenment thought, see David Brion Davis, The Problem of Slavery in the Age of Revolution (New York, 1999), 263; Susan Buck-Morss, Hegel, Haiti, and Universal History (Pittsburgh, 2009), 44; Louis Sala-Molins, Dark Side of the Light: Slavery and the French Enlightenment, trans. John Conteh-Morgan (Minneapolis, 2006); David Geggus, "Haiti and the Abolitionists: Opinion, Propaganda, and International Politics in Britain and France, 1804-1838," in Abolition and Its Aftermath: The Historical Context, 1790-1916, ed. David Richardson (London, 1985), 113-40. On the quandary of slave ownership for British colonial independence from imperial authority, see Jack P. Greene, "Liberty, Slavery, and the Transformation of British Identity in the Eighteenth-Century West Indies," Slavery and Abolition 21, no. 1 (April 2000): 1-31. John Donoghue cites early examples of analogies between slaves and poor Englishmen; see his "'Out of the Land of Bondage': The English Revolution and the Atlantic Origins of Abolition," American Historical Review 115, no. 4 (October 2010): 943-74.

- $\quad 54$ The eighteenth-century writer Nicolas Linguet saw in modern wage relations the progressive dehumanization of the lower classes, and he argued for the "necessity" of slavery in the face of that process. See Darlene Gay Levy, The Ideas and Careers of Simon-Nicolas-Henri Linguet (Chicago, 1980), 68. Along these lines, see also Myriam Cottias and Arlette Farge, eds., De la nécessité d'adopter l'esclavage en France, texte anonyme de 1797 (Paris, 2007), which argues for slavery in metropolitan France as a remedy to crime and poverty. Nineteenth-century political economy examined similar issues in the phenomenon of pauperism: see Jacques Donzelot, $L$ 'invention du social: Essai sur le déclin des passions politiques (Paris, 1984); and Giovanna Procacci, Gouverner la misère: La question sociale en France (Paris, 1993). Colonial emigration was often proposed as a solution: see Sessions, By Sword and Plow; Donald Winch, Riches and Poverty: An Intellectual History of Political Economy in Britain, 1750-1834 (Cambridge, 1996); and Claire Salinas, "Colonies without Colonists: Colonial Emigration, Algeria, and Liberal Politics in France, 1848-1870" (PhD diss., Stanford University, 2005). 
- 55 Girollet, Victor Scholcher, 272.

- $\quad 56$ Catherine Gallagher, The Industrial Reformation of English Fiction: Social Discourse and Narrative Form, 1832-1867 (Chicago, 1985). On Dickens, see Catherine Hall, Civilising Subjects: Metropole and Colony in the English Imagination, 1830-1867 (Chicago, 2002), 277.

- $\quad 57$ Pitts, A Turn to Empire, 241. As Martin Staum and Claude Blanckaert have discussed, the 1830 s and 1840 s were a period of developing race sciences, foreshadowing the later deterministic consensus signaled by the work of Arthur de Gobineau. Martin S. Staum, Labeling People: French Scholars on Society, Race, and Empire, 1815-1848 (Montreal, 2003); Claude Blanckaert, "Of Monstrous Métis? Hybridity, Fear of Miscegenation, and Patriotism from Buffon to Paul Broca," in The Color of Liberty: Histories of Race in France, ed. Sue Peabody and Tyler Stovall (Durham, NC, 2003), 42-70.

- $\quad 58$ Emmer, "The Price of Freedom," 29.

- $\quad \underline{59}$ Peter Stearns, Priest and Revolutionary: Lamennais and the Dilemma of French Catholicism (New York, 1967).

- $\quad 60$ For the relationship between social Catholicism and socialism in France, see Jean Duroselle, Les débuts du catholicisme social en France (1822-1870) (Paris, 1951); Frank Paul Bowman, Le Christ romantique (Geneva, 1973); and Edward Berenson, Populist Religion and Left-Wing Politics in France, 1830-1852 (Princeton, NJ, 1984).

- 61 There are a number of biographies and many analytical works on Tristan as both a feminist and a socialist. See, e.g., Joan S. Moon, "Feminism and Socialism: The Utopian Synthesis of Flora Tristan," in Socialist Women: European Socialist Feminism in the Nineteenth and Early Twentieth Centuries, ed. Marilyn A. Boxer and Jean H. Quataert (New York, 1978), 19-50; Rachel Nuñez, "Between France and the World: Cosmopolitanism and Nationalism in the Work of Flora Tristan," Proceedings of the Western Society for French History 34 (2006): 162-76; and Susan Grogan, Flora Tristan, Life Stories (New York, 1998), and French Socialism and Sexual Difference: Women and the New Society, 1803-1844(New York, 1992). On Tristan's impact on workers in Toulon, see Maurice Agulhon, "1844-1845: Le voyage de Flora Tristan et la grande grève de l'arsenal," in Une ville ouvrière au temps du socialisme utopique: Toulon de 1815 à 1851 (Paris, 1970), 154-77; and Màire Cross and Tim Gray, The Feminism of Flora Tristan (London, 1997).

- $\quad 62$ For more on Blanc, see Leo Loubère, Louis Blanc: His Life and Contribution to the Rise of French Jacobin-Socialism (Chicago, 1961).

- $\quad 63$ Félicité Lamennais, De l'esclavage moderne (Paris, 1839), 20.

- $\quad$ 64 Flora Tristan, Promenades dans Londres (Paris, 1840), 54.

- $\quad 65$ Ibid., 107.

- 66 The extent to which this aspect of the worker/slave analogy would have resonated in the period prior to the abolition of the slave trade is open to question. Living conditions and the reproduction of the slave population were more salient issues after 1807 and, in the French empire, after 1831, with the criminalization of slaving. For a discussion in the British context, see Kenneth Morgan, "Slave Women and Reproduction in Jamaica, 
c. 1776-1834," History 91, no. 302 (April 2006): 231-53.

- $\quad 67$ Tristan, Promenades dans Londres, 93.

- $\quad 68$ Ibid., 98 .

- $\quad 69$ For example, see Lamennais, De l'esclavage moderne, 42.

- $\quad 70$ Blanc, "De l'abolition de l'esclavage aux colonies," 3, 5.

- $\quad 71$ Ibid., 4.

- $\quad 72$ Ibid., 3; these are the opening lines of the essay.

- $\quad \underline{73}$ Ibid., 4-5.

- $\quad 74$ Ibid., 5 .

- $\quad \underline{75}$ Ibid., 16.

- $\quad$ 76 Lamennais, De l'esclavage moderne, 52.

- $\quad 77$ Sewell, Work and Revolution in France, 205-9; Tournier, "Quand un mot en cache d'autres: Le vocabulaire de 'L'Association' en 1848," Prevenir 13 (1986): 113-26; Pamela Pilbeam, French Socialists before Marx (Montreal, 2000), 8.

- $\quad 78$ On the role of Orleanist trade policies in the formation of organized labor after the Revolution of 1830, see William H. Sewell Jr., "Artisans, Factory Workers, and the Formation of the French Working Class, 1789-1848," in Working-Class Formation, ed. Ira Katznelson and Aristide R. Zolberg (Princeton, NJ, 1986), 45-70. See also the essays in John Merriman, ed., 1830 in France (New York, 1975).

- $\quad$ 79 Sewell, Work and Revolution in France, 202.

- $\quad 80$ For the positive reception of Fourier's ideas among Lyon silk workers, see Jonathan Beecher, "Le fouriérisme des canuts," in L'écho de la fabrique: Naissance de la presse ouvrière à Lyon, ed. Ludovic Frobert (Lyon, 2010), 111-39.

- $\quad 81$ On Fourier's followers, see Jonathan Beecher, Victor Considerant and the Rise and Fall of French Romantic Socialism (Berkeley, 2000). In the early 1820s, Fourier proposed a trial of his theory in Haiti and promised as well the emancipation of all slaves, "black and white." Jonathan Beecher, Charles Fourier: The Visionary and His World (Berkeley, 1986), 53, 357-58.

- $\quad$ 82 Although relevant and contemporaneous, Jules Lechevalier's plan for Guiana is not considered here because it has been thoroughly covered elsewhere. See n. 17 above.

- $\quad$ 83 Dain, De l'abolition de l'esclavage, suivi d'un article de M. Fourier; see n. 50 above. See also Charles Fourier, "Aveuglement du libéralisme," La Reforme Industrielle (July 12, 1833), t.2 n. 28 2nd année, 331.

- $\quad$ 84 Fourier, "Remède aux divers esclavages," in Dain, De l'abolition de l'esclavage, 43.

- $\quad 85$ Ibid., 46.

- $\quad \underline{86}$ Ibid.

- $\quad$ 87 Ibid., 44. Fourier calculates that his program would save the French nation from 
"bleeding" 300 million livres in resolving the slavery problem.

- $\quad \underline{88}$ Ibid., 47-48.

- $\quad 89$ Ibid., 51.

- $\quad 90$ Ibid., 51-52.

- $\quad 91$ Dain came from a planter family in Guadeloupe but was an early and apparently devoted advocate of abolition. Under the Second Republic, Dain was elected representative from Guadeloupe by the multiracial population of the island. Schmidt, Victor Scholcher et l'abolition de l'esclavage, 69. Schmidt suggests that Schœlcher was trying to mitigate any competition that Dain might represent and used Dain's family background as a pretext to remove him from the "postabolitionist debate"; see Schmidt, Abolitionnistes de l'esclavage, 199.

- $\quad 92$ Schmidt, Abolitionnistes de l'esclavage, 203.

- 93 Dain, De l'abolition de l'esclavage, 1.

- 94 Ibid., 10.

- $\quad 95$ Ibid., 28.

- $\quad 96$ Ibid., 20.

- 97 Ibid., 21-22.

- $\quad 98$ Ibid., 24-25.

- 99 Ibid., 34.

- $\quad \underline{100}$ Charles Dain, "Lettre au Courrier Français," La Démocratie Pacifique, March 12, 1847; reprinted in Schmidt, Abolitionnistes de l'esclavage, 649-54.

- $\quad 101$ Dain, De l'abolition de l'esclavage, 41.

- 102 Ibid.

- $\quad \underline{103}$ The British captured both Île Bourbon and Île de France in 1810 but returned Île Bourbon to French control in 1814. The British guaranteed French law and custom on Île de France, renamed Mauritius, leaving the slavery regime and social structure intact and in French hands. Anthony J. Barker, Slavery and Antislavery in Mauritius, 1810 1833 (New York, 1996). Mauritius was an anomalous colony both for the British and for the French before them, as it had a diverse ethnic makeup and was a successful sugar colony only in the closing decades of the slavery regime. A short-lived rebellion by the proslavery "French party" in 1832 was instrumental in turning British policy to full emancipation in 1833. Peter Burroughs, "The Mauritius Rebellion of 1832 and the Abolition of British Colonial Slavery," Journal of Imperial and Commonwealth History 4, no. 3 (1976): 244-65. On Mauritius, see Megan Vaughan,Creating the Créole Island: Slavery in Eighteenth-Century Mauritius (Durham, NC, 2005); on Réunion [Île Bourbon], see Françoise Vergès, Monsters and Revolutionaries: Colonial Family Romance and Métissage (Durham, NC, 1999).

- 104 In an article originally published in La Démocratie Pacifique, April 15, 1845, Laverdant invoked this superior experience in relation to attacks from the Journal des 
Débats; that article is reprinted in Laverdant, Aux habitants de l'île Bourbon, 42.

- $\quad 105$ Laverdant arrived in France at age nine and entered the law after studying at the École Polytechnique. His first encounter with Fourierism took place in 1832. He was a long-term member of the Fourierist École Sociétaire and is most famous for popularizing the term "avant-garde" in his De la mission de l'art et du rôle des artistes (Paris, 1845). He converted to Catholicism in 1848 while remaining an adherent of Fourierism; see Duroselle, Les débuts du catholicisme social, esp. 80-153, 359-412. For a brief overview of his life, see Neil McWilliam, Dreams of Happiness: Social Art and the French Left (Princeton, NJ, 1993), 246-51. For his involvement in the Fourierist movement, see Beecher, Victor Considerant; Paul Bénichou, Le temps des prophètes: Doctrines de l'âge romantique(Paris, 1977), 369, 373; and Astrid Léger, "Laverdant, Gabriel-Désiré (dit M. Petit-Jean),"http://www.charlesfourier.fr/article.php3? id article $=767$, accessed October 2011 .

- $\quad \underline{106}$ Laverdant, Aux habitants de l'île Bourbon, 49. The phrase is Fourier's and refers to the results of high public debt and resultant monopolies. See Beecher, Charles Fourier, 326.

- 107 Laverdant, Aux habitants de l'île Bourbon, 52.

- 108 Ibid., 58.

- $\quad 109$ Ibid., 33. Based on the dating of Aux habitants de l'île Bourbon, the pamphlet appears to be an argument for the adoption of association aimed at the colonial council of Bourbon, which in early 1848 considered and rejected such an idea in favor of continued slavery.

- $\quad 110$ Ibid., 30. De la Bâtie was also an observer of emancipation on Mauritius, in which context he argued that slaves there lived a life of "childlike joy"; Jennings, "Réflexions d'un observateur sur l'emancipation," 464 n. 9.

- $\quad 111$ Laverdant, "De la représentation des colonies dans le parlement," La Démocratie Pacifique, August 6-7, 1847; reprinted in Laverdant, Aux habitants de l'île Bourbon, 50.

- $\quad 112$ Ibid., 31, 43. Laverdant's protestations of impartiality are of questionable veracity, though they are repeated throughout the work and elsewhere in La Démocratie Pacifique. See Jennings, "Slavery and the Venality of the July Monarchy Press," and "French Slave Liberation and 'Socialism,"' 104.

- $\quad 113$ Laverdant, Aux habitants de l'île Bourbon, 32.

- 114 Ibid., 36 .

- $\quad \underline{115}$ Ibid. Laverdant's reference to British "saints" presumably means the leaders of the abolitionist lobby at the time. According to Christopher Brown, the term was one of derision attached to the Clapham sect by their critics. Brown, Moral Capital, 334.

- $\quad \underline{116}$ Laverdant, Aux habitants de l'île Bourbon, 44; emphasis in original. Laverdant calls for economic investment in the society as a whole rather than for either planters (as compensation) or "industrious" slaves (see 48-49).

- $\quad 117$ Ibid., 34. Vergès, Monsters and Revolutionaries, 3-8, shows that familial metaphors 
in the postcolonial era have helped to erase the memory of slavery in Réunion.

- 118 Laverdant, Aux habitants de l'île Bourbon, 34.

- 119 Ibid., 45-46. The Mackau laws guaranteed, among other things, the right of selfpurchase to slaves and increased government oversight over planter treatment of slaves; as Jennings reports, the government was newly interested in a rapprochement with the British and supported these laws partially in service of that goal. The French abolition society was originally opposed to the bill but eventually came around to supporting it, while the planters were themselves divided, some believing that the law would delay emancipation, others that it would erode the system and reduce the likelihood of indemnity payments and thus the value of their property. Jennings, French Anti-slavery, 213-14.

- $\quad 120$ See Laverdant, Aux habitants de l'île Bourbon, 46n.

- 121 Laverdant's search for a middle ground between what he calls the "entrenched" colonial position and the liberals' position led to his energetic endorsement of the Guadeloupe colonial council's offer, tendered by the aging general Ambert, to emancipate their slaves voluntarily if structured through "association." According to Jennings, the Guadeloupe planters' proposal was a last-ditch effort on the part of an endangered colonial order to maintain its economic viability. Disputing the genuineness of the planters" adherence to "socialism," he describes the colonial council of Guadeloupe as dominated by landowners "overreacting to the Mackau laws." Jennings, "French Slave Liberation and 'Socialism,", 98. Jennings takes issue with Drescher's apparent acceptance of the progressive nature of the Guadeloupe plan; see Drescher, "British Way, French Way," 728.

- $\quad 122$ A significant portion of Aux habitants de l'île Bourbon is devoted to denouncing not only de la Bâtie but also the baron Dupin and Jollivet of Martinique, whom Laverdant characterizes as "the three delegates who represent the Old Regime" (69). On Dupin's antiabolitionist stance, see Francis Démier, "Charles Dupin: Un libéralisme sans doctrine?" in Charles Dupin (1784-1873): Ingénieur, savant, économiste, pedagogue, et parlementaire du Premier au Second Empire, ed. Carole Christen and François Vatin (Rennes, 2009), 169-76.

- $\quad 123$ Laverdant, La Démocratie Pacifique, June 11, 1844 (during debates on the Mackau laws); reprinted in Laverdant, Aux habitants de l'île Bourbon, 72-73.

- $\quad 124$ Laverdant, Aux habitants de l'île Bourbon, 50.

- $\quad 125$ Ibid., 49.

- $\quad 126$ Ibid., 50. Laverdant had experimented on Mauritius in the 1830s with model schools for emancipated slaves. See Jean Fornasiero, "Vers une histoire du fouriérisme à l'île Maurice," Cahiers Charles Fourier, no. 18 (December 2007); on Fourierism on Mauritius, see Raymond d'Unienville,Tentative socialiste à l'île Maurice (1846-1851) (Port Louis, 1900).

- $\quad 127$ Laverdant, Aux habitants de l'île Bourbon, 65-68.

- 128 See the addresses by General Ambert reprinted in Schmidt, Abolitionnistes de 
l'esclavage, 951-57.

- $\quad 129$ Laverdant, Aux habitants de l'île Bourbon, 33.

- $\quad 130$ Fourierism was used far more explicitly in the United States to argue for continued enslavement of the black populations. See Carl J. Guarneri, "Two Utopian Socialist Plans for Emancipation in Antebellum Louisiana," Louisiana History: The Journal of the Louisiana Historical Association 24, no. 1 (Winter 1983): 5-24, and The Utopian Alternative: Fourierism in Nineteenth-Century America (Ithaca, NY, 1994), 252.

- $\quad 131$ Laverdant, Aux habitants de l'île Bourbon, 38.

- 132 Ibid.

- $\quad \underline{133}$ Ibid., 128.

- 134 Ibid., 47.

- $\quad 135$ Schmidt, Victor Schœlcher et l'abolition de l'esclavage, 115. It must be remembered that in addition to the economic and social constraints imposed upon the formerly enslaved, universal manhood suffrage, made law by the Second Republic, was essentially vitiated for more than twenty years under Napoleon III. When it was reinstated in 1871, voter participation in Guadeloupe and Martinique hovered under 20 percent. Oruno D. Lara, Space and History in the Caribbean (Princeton, NJ, 2006), 75.

- 136 Schmidt, Victor Scholcher et l'abolition de l'esclavage, 115-16.

- $\quad 137$ Indemnity payments were guaranteed by the decree of April 27, 1848, but they began to be distributed only at the end of 1851; the colonial banks that were to fulfill the economic needs of the new wage labor system were stalled until 1853. Ibid., 115.

- 138 Dobie, Trading Places, 288.

- $\quad 139$ Lara, Space and History, 73.

- $\quad 140$ Sarda Garriga, quoted in Laroche, Histoire de l'abolition de l'esclavage, 24.

- 141 Schœlcher's investment in the colonial order and in the stabilization of the colonial labor force is highlighted by Lara, La colonisation est aussi un crime, 67.

- $\quad 142$ Schmidt, Victor Schoelcher et l'abolition de l'esclavage, 116.

- $\quad 143$ Lara, La liberté assassinée. Dobie notes the predominantly mercantilist nature of the economic ties of France to its overseas departments; see Dobie, Trading Places, 288.

- 144 Schmidt, La France, a-t-elle aboli l'esclavage? 11.

- $\quad 145$ Lara, Space and History, 75. Dobie similarly argues that the commitment of eighteenth-century thinkers to the economic viability of the colonies was one of the brakes on the development of antislavery in eighteenth-century France. She rightly points out that though devoted to immediatist emancipation, Victor Schœlcher presumed that the labor force would remain stable and would multiply in the aftermath of emancipation, thus producing the wage labor force feared by the socialists discussed above. See Dobie, Trading Places, 205 n. 12.

- $\quad 146$ Dubois, A Colony of Citizens, 3. 
- $\quad 147$ Lechevalier and Laverdant also promoted settler colonialism as a component of their slave emancipation programs. See Désiré Laverdant, Colonisation de Madagascar (Paris, 1844); and Jules Lechevalier, Note sur la fondation d'une nouvelle colonie dans la Guyane française; ou, Premier aperçu d'un nouveau mode de population et de culture pour l'exploitation des régions tropicales: suivi de plusieurs pièces et documents, etc. (Paris, 1844).

(C) 2013 by The University of Chicago. All rights reserved. 